\title{
Occupational and Environmental Causes of Lung Cancer
}

\author{
R. William Field, PhD, MS ${ }^{a,{ }^{*}}$ and Brian L. Withers, DO $^{\text {b }}$ \\ aDepartment of Occupational and Environmental Health, Department of Epidemiology, College of \\ Public Health, University of lowa, 105 River Street, lowa City, IA 52242, USA \\ bepartment of Occupational and Environmental Health, Occupational Medicine, Heartland \\ Center for Occupational Health and Safety, College of Public Health, University of lowa, 105 \\ River Street, lowa City, IA 52242, USA
}

\section{Keywords}

Lung; Cancer; Environmental; Occupational; Carcinogen; Epidemiology; International Agency for Research on Cancer

\section{BRIEF EPIDEMIOLOGY OF LUNG CANCER}

Although lung cancer incidence rates started to slowly decrease for men in the 1980s followed by declining incidence rates for women in the late $1990 \mathrm{~s},{ }^{1}$ lung and bronchus cancer remain the leading cause of cancer mortality in the United States, with an estimated 87,750 and 72,590 deaths predicted to occur in men and women, respectively, in $2012 .{ }^{2}$ Globally, approximately $75 \%$ of lung cancer cases are attributable in part to smoking tobacco, with a higher estimate of $85 \%$ to $90 \%$ for the United States. ${ }^{3-6}$ Of note, women are more likely than men to have nonsmoking-related lung cancer. ${ }^{7,8}$ In a study of 6 large prospective epidemiologic cohort studies primarily performed in the United States, Wakelee and colleagues ${ }^{8}$ found that the age-adjusted lung cancer incidence rates for individuals 40 to 79 years of age who never smoked ranged from 14.4 to 20.8 per 100,000 person-years in women and 4.8 to 13.7 per 100,000 person-years in men.

Because tobacco smoking is a potent carcinogen, secondary causes of lung cancer are often diminished in perceived importance. If considered in its own disease category, however, lung cancer in never smokers would represent the seventh leading cause of cancer mortality globally, surpassing cancers of the cervix, pancreas, and prostate, ${ }^{5}$ and among the top 10 causes of death in the United States. ${ }^{7,9}$ Because of the significant number of lung cancer deaths occurring among individuals who have never smoked, it is apparent that there are important risk factors for lung cancer other than tobacco smoking that can contribute substantially to the lung cancer mortality in never smokers. ${ }^{5,7,9-12}$ In fact, these other lung carcinogens often act in an additive or synergistic manner in individuals who smoke tobacco products. ${ }^{13,14}$

In a frequently cited paper published in 1981, Doll and Peto ${ }^{15}$ estimated that occupational exposures are responsible for $15 \%$ and $5 \%$ of lung cancer in men and women, respectively, in the United States. The 2008 to 2009 President's Cancer Panel Report ${ }^{16}$ indicated that the cancer risk estimates suggested by Doll and Peto, ${ }^{15}$ as well as risk estimates from similar

(C) 2012 Elsevier Inc. All rights reserved.

${ }^{*}$ Corresponding author. bill-field@ uiowa.edu.

Conflict of interest: No Conflicts. 
studies, ${ }^{17,18}$ "are woefully out of date, given our current understanding of cancer initiation as a complex multifactorial, multistage process."

To complicate risk assessment further, the Panel ${ }^{16}$ pointed out that fewer than $10 \%$ of the more than 80,000 chemicals currently in use in the United States have been evaluated for safety. The primary objective of this article is to provide a brief overview of the environmental and occupational lung carcinogens currently listed by the International Agency for Research on Cancer (IARC) as known human lung carcinogens. Supplementary new information, with a focus on analytic epidemiologic studies that have become available since IARC's most recent evaluation, is also discussed.

\section{IARC GROUP 1 LUNG CARCINOGENS AND CARCINOGENIC AGENTS}

The IARC prepares, with the assistance of international working groups of experts, evaluations of carcinogenicity for a wide range of human exposures.

The IARC classifies agents as follows:

- Carcinogenic to humans (Group 1)

- Probably carcinogenic to humans (Group 2A)

- Possibly carcinogenic to humans (Group 2B)

- Not classifiable as to its carcinogenicity to humans (Group 3)

- Probably not carcinogenic to humans (Group 4)

Agents classified as known Group 1 lung carcinogens are listed in Table 1 and include the categories of ionizing radiation, chemicals and mixtures, occupational exposures, metals, dust and fibers, personal habits, and other exposures. Starting in 2009, several IARC panels reassessed the carcinogenicity of Group 1 agents in each of the categories listed. The assessments were published in 2012 as Volume $100 \mathrm{C}$ through F of the IARC Monographs, see http://monographs.iarc.fr/ENG/Monographs/PDFs/index.php.

One of the agents, indoor emissions from household combustion (eg, coal), is predominantly an environmental lung carcinogen; 16 agents are primarily occupational lung carcinogens (although environmental exposures occur); and 8 agents are both potential environmental and occupational lung carcinogens. For purposes of this overview on occupational and environmental lung carcinogens, the chemotherapy regimen of mechlorethamine, oncovin, procarbazine, and prednisone (MOPP), which was developed in the 1960s to treat Hodgkin lymphoma, ${ }^{19}$ as well as the well-known IARC Group 1 carcinogens (tobacco smoking, indoor emissions from household combustion [eg, coal], and secondhand tobacco smoke, also referred to as environmental tobacco smoke), are not discussed. A detailed discussion on secondhand smoke is presented in an earlier article by Dela Cruz and colleagues ${ }^{14}$ in this journal. Discussion concerning the health effects of tobacco smoking ${ }^{14,20}$ are limited to describing selected interactions with other lung carcinogens.

\section{IARC Group 1 Lung Carcinogens: lonizing Radiation}

All types of ionizing radiation have been documented to be carcinogenic to humans (ie, Group 1). The types of radiation primarily identified as lung carcinogens are a-particles, $\gamma$ rays, and x-rays. ${ }^{21} \mathrm{Fig} .1$ displays the relative contribution of the various sources of radiation to the US population. ${ }^{22}$ Nearly half (48\%) of the average individual's radiation exposure in the United States comes from medically related procedures, with most of the remaining radiation exposure coming from exposure to radon-222 decay products. ${ }^{22}$ 
lonizing radiation: $\boldsymbol{\alpha}$-particles-All internalized radionuclides that emit a-particles, including radon-222 decay products and plutonium-239, are classified as Group 1 carcinogens by IARC. ${ }^{23}$ Alpha-particles are somewhat unique among occupational and environmental carcinogens, because of their ability to produce a higher relative rate of double-strand DNA breaks compared with other types of ionizing radiation. Cells that have been hit by an a-particle, as well as nearby cells (ie, the so-called "bystander effect"), ${ }^{24}$ may undergo genetic changes that lead to cancer. ${ }^{25}$ Alpha-particles can also produce reactive oxygen intermediates that can produce oxidative damage to the DNA. ${ }^{25}$ A single bronchial epithelial cell that has sustained genetic damage can initiate lung cancer ${ }^{25}$ Because cancer is thought to originate from a single cell (ie, monoclonal) that has completed the process of malignant transformation, it is unlikely a threshold exists for a-particle-induced lung cancer. ${ }^{25}$ For additional information on the lung cancer risk posed by alpha particles, see http://monographs.iarc.fr/ENG/Monographs/vol100D/mono100D.pdf.

Ionizing radiation (a-particles): radon-222 and its decay products: Radon-222 (radon) and its decay products are the oldest known occupational carcinogens. ${ }^{26-29}$ Radon is a colorless radioactive noble gas with a half-life of 3.8 days that is formed as part of the uranium-238 decay chain. ${ }^{30}$ Because several of the radionuclides (ie, uranium-234, thorium-230, and radium-226) between uranium-238 and radon-222 have relatively long half-lives, there is a constant source of radon production in the ground (eg, soil, rocks, groundwater). Although radon occurs naturally outdoors, radon can accumulate in underground structures, such as mines, as well as built environments, such as homes, offices, and schools. ${ }^{30}$ The potential for radon exposure varies by geographic areas (eg, see http://www.epa.gov/radon/pdfs/zonemapcolor.pdf); however, even structures built in areas with low radon potential can exhibit greatly elevated radon concentrations.

As radon undergoes radioactive decay, it produces a series of solid radioactive decay products that can be inhaled. Two of the short-lived radon decay products, polonium-218 and polonium 214, deliver most of the radiation dose, via a-decay, to the bronchial epithelial cells. Deposition of radon decay products in the lung depends on several factors, including particle size, tidal lung volume, respiratory rate, and lung volume. ${ }^{25,30}$

The causative link between protracted radon decay product exposure and lung cancer has been firmly documented in the numerous retrospective mortality studies of uranium and hard rock underground miners performed throughout the world. In the late 1990s, the National Research Council's Biologic Effects of Ionizing Radiation (BEIR) VI Committee pooled the raw data from 11 major retrospective mortality studies of uranium and hard rock underground miners. ${ }^{25}$ The study included approximately 68,000 miners with $1.2 \mathrm{M}$ personyears of follow-up and more than 2700 lung cancer deaths. Each of the 11 studies reported significantly increased lung cancer mortality with increasing exposure to radon decay products and a synergistic (albeit sub-multiplicative) interaction between cigarette smoking and radon decay product exposure. The BEIR VI committee also performed a subset study of miners who had a mean radon exposure of 14.8 Working Level Months (WLMs) (14 $\times$ $10^{-5}$ per $\mathrm{mJ} \mathrm{h} \mathrm{m}^{-3}$ ). The risk estimates for this subgroup that was exposed to radon exposures comparable to protracted exposure at the Environmental Protection Agency's (EPA) action level of $4 \mathrm{pC} / \mathrm{L}$ (ie, $14.8 \mathrm{WLMs}$ ) were similar to the findings using the overall pooled data set. ${ }^{25,31}$ Based on the pooled results, the International Commission on Radiological Protection ${ }^{32}$ recently indicated that a lifetime excess absolute risk of $5 \times 10^{-4}$ per WLM should be used as the nominal probability coefficient for radon progeny-induced lung cancer.

Although Fig. 1 indicates that occupational exposure to ionizing radiation accounts for less than $0.1 \%$ of the average individual's radiation exposure in the United States, 30 years of 
exposure at the current Mine Safety and Health Administration's and Occupational Safety and Health Administration's (OSHA) permissible exposure limit for cumulative radon decay product exposure of 4 WLMs per year would result in a $6 \%$ increase in lifetime risk of lung cancer. ${ }^{33}$ Since the publication of the BEIR VI report, additional miner studies have been published that continue to support the original risk estimates from the miner cohort studies. ${ }^{32-37}$

In addition to radon's role as an occupational lung carcinogen, radon exposure occurring outside the workplace also presents an important environmental lung cancer risk. Based on projections from the radon-exposed underground miner studies, the BEIR VI Committee estimated (ie, central risk estimate based on 2 models) that approximately 18,600 lung cancer deaths occur each year in the United States from nonoccupational radon decay product exposure..$^{25}$ In 2003, the EPA updated the estimate to $21,100(13.4 \%)$ of the total 157,400 lung cancer deaths that occurred in the United States in $1995 .{ }^{37}$ The EPA projected that a lifetime exposure at the EPA's radon action level (ie, $4 \mathrm{pCi} / \mathrm{L}$ ) yields a $2.3 \%$ risk of lung cancer for the US population overall, $4.1 \%$ for individuals who smoked at least 100 cigarettes in their lives, and $0.73 \%$ for individuals who never smoked. ${ }^{38}$

To directly examine the risk of protracted radon exposure in the residential setting, 22 major case-control residential radon studies were performed in the late 1980s and 1990s. ${ }^{30,31,39-42}$ Two of the studies were performed in China, ${ }^{39} 13$ in Europe, ${ }^{40}$ and 7 in North America. ${ }^{41}$ Of the 22 case-control studies, 19 reported increased risk estimates at $2.7 \mathrm{pCi} / \mathrm{L}(100 \mathrm{~Bq} /$ $\left.\mathrm{m}^{3}\right),{ }^{31}$ which is below the EPA radon action level of $4 \mathrm{pCi} / \mathrm{L}$. The raw data from Chinese, North American, and European studies were pooled to increase study power. The pooled odds ratios (ORs) at $2.7 \mathrm{pCi} / \mathrm{L}\left(100 \mathrm{~Bq} / \mathrm{m}^{3}\right)$ for the China, Europe, and North America case control studies were 1.13 (95\% confidence interval [CI] 1.01-1.36), 1.08 (95\% CI 1.031.16), and 1.11 (95\% CI 1.00-1.28), respectively. After corrections for random uncertainties in radon assessment, the OR for the European pooling increased to 1.16 (95\% CI 1.05-1.31). A similar increase in the OR was also noted for the North American pooled analyses when data were restricted on the basis of completeness of radon measurement data. Although other potential sources of nondifferential radon exposure misclassification could not be ruled out, it would tend to bias the observed association toward the null (eg, the true effect is underestimated). ${ }^{42}$

In summary, after stratification for smoking, the pooled analyses provided direct evidence of an association between protracted residential radon exposure and lung cancer. The studies exhibited a linear dose-response relationship with no evidence of a threshold with risk estimates very comparable to the OR of 1.12 (95\% CI 1.02-1.25) extrapolated from the BEIR VI risk models for radon. The findings of the pooled analyses suggest that $8 \%$ to $15 \%$ of the lung cancer risk in Europe and North America is attributable to radon decay product exposure. ${ }^{41}$ Because of the large population at risk and the widespread potential for protracted exposures, residential radon decay products are likely the leading environmental cause of cancer mortality in the United States ${ }^{30,43}$ and the seventh leading cause of cancer mortality overall (Fig. 2). For additional information on the lung cancer risk posed by radon, see www.breathingeasier.info.

Ionizing radiation (a-particles): plutonium-239: Plutonium-239 $\left({ }^{239} \mathrm{Pu}\right)$ is a manmade silvery gray radioactive metal, with a 24,110-year half-life, that undergoes radioactive decay by a-particle emission. Its primary use is in nuclear weapons and nuclear power production (ie, mixed-oxide fuel). ${ }^{44}$ In the United States, workers involved with the chemical or mechanical processing of plutonium for nuclear weapons production are at greatest risk of exposure. ${ }^{44}$ The primary source of exposure for nuclear workers is inhalation of dust contaminated with ${ }^{239} \mathrm{Pu}$. After inhalation of ${ }^{239} \mathrm{Pu}$, it is redistributed primarily to lung, 
liver, and bone. ${ }^{4,45}$ Pulmonary absorption of inhaled plutonium follows a 2-phase model with absorption half-times of months and years.

The IARC's 2001 evaluation of the carcinogenicity of ${ }^{239} \mathrm{Pu}$ relied primarily on the doseresponse relationship findings ${ }^{45}$ for ${ }^{239} \mathrm{Pu}$ exposure and lung cancer for highly exposed workers at the Mayak Nuclear Processing Plant in the Russian Federation. Although studies ${ }^{46-48}$ performed in the United States have only suggested increased lung cancer risk for ${ }^{239} \mathrm{Pu}$-exposed workers, the causal relationship was strengthened in IARC's 2012 evaluation, ${ }^{45}$ which reported on several follow-up studies of ${ }^{239} \mathrm{Pu}$-exposed Mayak workers that incorporated improved assessment of smoking, dosimetry, and work history data. ${ }^{46-55}$ Overall, the follow-up studies reported a statistically significant dose-response relationship between estimated ${ }^{239} \mathrm{Pu}$ lung dose and lung cancer, with no observed departure from linearity or threshold. The most recent follow-up study, ${ }^{53}$ published in 2008 , estimated excess relative risks for lung cancer per gray (Gy) at attained age 60 years, with adjustment for smoking, was 7.1 (95\% CI 4.9-10.0) for males and 15 (95\% CI 7.6-29.0) for females. For additional information on ${ }^{239} \mathrm{Pu}$, see http://monographs.iarc.fr/ENG/Mono graphs/ vol100D/mono100D.pdf.

\section{lonizing Radiation: X-rays and $\mathbf{Y}$-Rays}

A large proportion of the $\mathrm{x}$-ray dose received by the average person in the United States each year is from medically related external exposure from computed tomography (24\%), interventional fluoroscopy (7\%), or conventional radiography and fluoroscopy procedures $(5 \%)$ (see Fig. 1). The percentage of the total effective dose has increased for these procedures, as well as for nuclear medicine procedures that often use $\gamma$-ray emitting radioisotopes (eg, inhalation of technetium-99 $\mathrm{m}$ for lung scans). In fact, the collective dose received by the US population in the early 1980 s was 7 times lower than in $2006 .^{22}$ The low proportion of occupational exposure (ie, $<0.1 \%$ ) observed in Fig. 1 reflects the low percentage of workers in the United States who are at risk for radiation exposure (eg, nuclear power workers, $\mathrm{x}$-ray technicians), as well as the low percentage who received recordable radiation doses.

The IARC previously classified $x$-rays and $\gamma$-rays as Group 1 lung carcinogens in $2000^{23}$ based primarily on the findings of the Lifespan Study (LSS) of atomic bomb survivors in Hiroshima and Nagasaki, Japan. Lung cancer was the second leading type of cancer, following stomach cancer, in the LSS cohort. The recent 2012 IARC monograph ${ }^{23}$ continues to update x-ray and $\gamma$-ray cancer risk estimates based primarily on findings from the LSS cohort, ${ }^{56,57}$ as well as with supplemental findings from populations exposed to medical procedures..$^{58}$

In a more recent study, not included in the IARC review, ${ }^{45}$ that included 105,404 LSS subjects and 1803 primary lung cancer incident cases that were identified for the period 1958 to 1999 , Furukawa and colleagues ${ }^{59}$ reported that relative to individuals who never smoked, the joint effect between radiation and smoking was super-multiplicative for light or moderate smokers, with a rapid increase in excess risk with smoking intensity up to about 10 cigarettes per day. For smokers who smoked a pack or more per day, however, the investigators reported the joint effect was additive or subadditive. The non-gender-specific average excess relative risk per Gy at attained age 70 was 0.59 (95\% CI $0.31-1.00$ ) for nonsmokers, with a female:male ratio of 3.1. The investigators concluded that the "joint effect of smoking and radiation on lung cancer in the LSS is dependent on smoking intensity and is best described by the generalized interaction model rather than a simple additive or multiplicative model." For additional information on the lung cancer risk posed by $\mathrm{x}$-ray and $\gamma$-ray exposure, see http://monographs.iarc.fr/ENG/Monographs/vol100D/index.php. 


\section{IARC Group 1 Lung Carcinogens: Chemicals and Mixtures}

\section{Bis(chloromethyl)ether; technical-grade chloromethyl methyl ether-}

Bis(chloromethyl)ether (BCME) and technical-grade chloromethyl methyl ether (CMME) were manufactured before 1976 in the United States, but because of their lung carcinogenicity, the use of these chemicals has been reduced substantially in the United States. ${ }^{60}$ BCME and CMME were used as alkylating agents and chemical intermediates. Technical-grade CMME contains $1 \%$ to $8 \%$ BCME. ${ }^{61}$ The greatest potential for past occupational exposure to $\mathrm{BCME}$ or CMME was for ion-exchange resin makers, chemical plant workers, laboratory workers, and specialty polymer makers. ${ }^{60}$

In a worker survey conducted from 1981 to 1983, the National Institute for Occupational Safety and Health (NIOSH) estimated that a total of 14 laboratory workers were potentially exposed to BCME. ${ }^{61}$ There was no estimate of potential exposure to CMME. In the past, a significant potential for environmental exposure to BCME arose from the use of mosquito coils that contain octachlorodipropyl ether, also referred to as "S-2." Although the EPA does not register S-2 for any current use, there have been some concerns about illegal sales of imported mosquito coils containing S-2. ${ }^{62} \mathrm{BCME}$ can be produced by the burning of mosquito coils from impurities present in the S-2 or by the thermolytic degradation of S-2. ${ }^{63}$

Based on numerous studies of exposed workers, the IARC states that BCME is among the most potent human carcinogens known. The fact that BCME and CMME are both alkylating agents provides support that their mode of action is genotoxic. Six epidemiologic studies performed in 1970 documented statistically significant increases in the relative risks for lung cancer for exposures to BCME. In 4 of the studies, the primary exposure was from technical-grade CMME with $1 \%$ to $8 \%$ contamination from BCME. ${ }^{64}$ The histologic type of lung cancer most often associated with the exposures was small cell carcinoma. ${ }^{65}$ For additional information on the lung cancer risk posed by BCME and CMME, see http:// monographs.iarc.fr/ENG/Monographs/vol100F/mono100F-25.pdf.

Sulfur mustard-Sulfur mustard, called mustard gas in the military sector, is primarily a chemical warfare agent. Occupational exposures can also occur during its storage and destruction or from inadvertent exposure near dumping areas or areas where contamination may have occurred in the past (eg, military installations, demolition of old buildings). Findings from numerous studies performed between 1950 and 2000 detailing the adverse effects of short-term battlefield exposure and prolonged exposure in chemical factories firmly established the lung carcinogenicity of sulfur mustard. ${ }^{66}$ The genotoxicity of sulfur mustard is primarily attributed to its behavior as a bi-functional alkylating agent. ${ }^{67}$ For additional information on the lung cancer risk posed by sulfur mustard, see http:// monographs.iarc.fr/ENG/Monographs/vol100F/mono100F-30.pdf.

Coal-tar pitch-Coal-tar pitch is the solid residue remaining from the distillation of coal tars. The actual composition of coal-tar pitch depends on the source materials used that resulted in the coal tars and the distillation temperature. Coal tars are composed primarily $(90 \%)$ of 3-membered to 7-membered polycyclic aromatic hydrocarbons (PAHs), as well as their methylated derivative with lower concentrations of phenolic compounds and nitrogen bases. ${ }^{68}$ Potential sources of occupational exposure to volatile PAHs (eg, acridine, anthracene, benzo[a] pyrene, chrysene, pyrene, phenanthrene) from coal tar include foundry and coal gasification processes and the production of coke, aluminum (eg, carbon electrodemanufacturing), pavement tar, roofing tar, coal tar paints, sealants, and refractory bricks. ${ }^{68}$

IARC working groups that met in 2005 and again in 2009 determined that there was sufficient evidence from epidemiologic studies of road pavers and roofers to support the carcinogenicity of coal-tar pitch. ${ }^{68,69}$ Even though coal-tar pitch was phased out in the 
1960s and 1970s in many of the European countries where the epidemiologic studies were performed, studies focused on the adverse health effects of bitumen exposure continue to observe suggestive evidence of coal tar's lung carcinogenicity. ${ }^{70,71}$ For additional information on the lung cancer risk posed by coal tar pitch, see http://monographs.iarc.fr/ ENG/Monographs/vol100F/mono100F-17.pdf.

\section{Soot, as found in occupational exposure of chimney sweeps-Soot is a}

carbonaceous by-product material produced from the incomplete conversion of fossil fuel or other carbon-containing material (eg, paper, plastics) to combustion products (eg, water vapor, $\mathrm{CO}_{2}$ ). Soot contains up to $60 \%$ carbon, inorganic material, and a soluble fraction consisting primarily of PAHs. ${ }^{72}$ Occupations with higher potential for soot exposure include chimney sweeps; firefighters; brick masons and helpers; heating, ventilation, and air conditioning personnel; and others that require work near where organic matter is burned. ${ }^{72}$ Chimney sweeps, in particular, have a high potential for exposure to soot. In 2006, there were more than 1000 members of the National Chimney Sweep Guild, which represents fewer than $50 \%$ of the chimney sweeps in the United States. ${ }^{73}$

Two epidemiologic studies of chimney sweeps performed in Sweden and Finland in the 1990s reported elevated lung cancer risks for chimney sweeps from soot exposure. These studies provided the basis for the IARC to classify soot, as found in occupational exposure of chimney sweeps, a human lung carcinogen. ${ }^{74}$ Adjustment for smoking was performed at the group level for the Swedish study and by use of social class for the Finnish study. An occupational cohort study by Pukkala and colleagues ${ }^{75}$ that accessed 45 years of cancer incidence data by occupational category for individuals aged 30 to 64 years in the 1960, 1970, 1980/1981, and/or 1990 censuses provided further support that soot is a lung carcinogen. In the study published in $2009,{ }^{75}$ a total of 212 incident lung cancers were observed in chimney sweeps from Denmark, Finland, Norway, and Sweden, resulting in a standardized incidence ratio of 1.49 (95\% CI 1.3-1.7) for lung cancer for chimney sweeps. For additional information on the lung cancer risk posed by soot, see http:// monographs.iarc.fr/ENG/Monographs/vol100F/mono100F-21.pdf.

Diesel engine exhaust-According to McDonald and colleagues, ${ }^{76}$ diesel engine exhaust contains a variety of gas and particulate matter constituents, including black carbon, organic carbon, nitrate, carbon monoxide, non-methane volatile organic compounds, sulfate, ammonium, alkanes, naphthalenes, phenanthrenes, and various polyaromatic hydrocarbons. In addition, the relative composition of the exhaust is significantly influenced by fuel type, engine type and condition, engine operation, engine load, and pretreatment (eg, particle traps) of exhaust. ${ }^{76}$ Certain occupations (eg, underground miners, truck and bus drivers, toll booth attendants, construction workers) are known to have increased risk of exposure to diesel exhaust, with documented higher exposures of elemental carbon associated with enclosed underground mining and construction operations. ${ }^{77}$ There is also widespread diesel engine exhaust exposure to the general population.

Diesel engine exhaust had been listed by the IARC since 1998 as possibly carcinogenic to humans (Group 2B).$^{78}$ Because of increasing epidemiologic evidence, however, originating from a variety of occupational settings, that exposure to diesel engine exhaust is a human carcinogen, the IARC convened a working group to review the existing evidence. ${ }^{79}$ After review of the available information, the IARC work group added diesel engine exhaust as a Group 1 carcinogen on June 12, 2012 (Fig. 3) ${ }^{80}$ Although the specific findings supporting their decision had not yet been published in monograph form at the time of this writing, the IARC indicated that their decision was based on the mounting evidence, ${ }^{81}$ including 2 metaanalyses and a pooled epidemiologic study, that diesel engine exhaust is a known human lung carcinogen. The IARC specifically mentioned the recent results of a nested study 
performed by Silverman and colleagues ${ }^{82}$ within a cohort of workers from 8 nonmetal mining facilities that provided strong support for the lung carcinogenicity of diesel engine exhausts.

The study by Silverman and colleagues, ${ }^{82}$ which included 198 lung cancer deaths, reported a statistically significant positive trend between estimated respirable elemental carbon exposure (used as a marker of the mixed particulate and gaseous components of diesel exhaust), lagged 15 years, and a statistically significant increased lung cancer risk $(P=.001)$ after adjustment for smoking and other potential confounders. For workers with heavy exposure to respirable elemental carbon (ie, above the median of the top quartile [respirable elemental carbon $\left.\geq 1005 \mu \mathrm{g} / \mathrm{m}^{3}-\mathrm{y}\right]$ ), the reported risk was approximately 3 times greater $(\mathrm{OR}=3.20,95 \% \mathrm{CI}=1.33-7.69)$ as compared with workers in the lowest quartile of exposure. The effect of cigarette smoking among study subjects was attenuated among workers with higher past diesel exposure estimated using respirable elemental carbon. Dr Kurt Straif, head of the IARC Monographs Program, stated that although IARC's conclusions regarding the lung carcinogenicity of diesel engine exhaust were based on rigorous epidemiologic studies of highly exposed workers, "we have learned from other carcinogens, such as radon, that initial studies showing a risk in heavily exposed occupational groups were followed by positive findings for the general population. Therefore actions to reduce exposures should encompass workers and the general population." ${ }^{80}$ For additional information on the lung cancer risk associated with diesel exposure, see http://www.iarc.fr/en/media-centre/iarcnews/2012/mono105backgrounderQ_A.php.

\section{IARC GROUP 1 LUNG CARCINOGENS: OCCUPATIONS AND MANUFACTURING PROCESSES}

The 2009 IARC work group determined that there was sufficient evidence in humans for the carcinogenicity of occupational exposures occurring during work activities in the following 6 discrete occupational categories ${ }^{83}$ :

- Coal gasification

- Coke production

- Iron and steel founding

- Aluminum production

- Painting

- Rubber production industry

\section{Coal Gasification, Coke Production, Iron and Steel Founding, Aluminum Production}

The occupational groupings of coal gasification, coke production, iron and steel founding, and aluminum production, all have potential for high exposure to PAHs, as well as to other chemicals, especially in the 1950s to 1990s when many of the occupational cohort epidemiologic studies were performed. The evidence for the positive dose-response relationship noted for many of the cohort studies, which were cited by the IARC ${ }^{83}$ to help establish the evidence for the carcinogenicity of that occupational grouping, used benzo(a)pyrene as a surrogate exposure measure of PAHs. It is noteworthy that although IARC has not listed benzo(a)pyrene as a lung carcinogen based on epidemiologic data, it has listed benzo(a)pyrene as a Group 1 carcinogen based on mechanistic and experimental animal studies indicating that it is likely to be a human carcinogen. 
In a combined study of cohorts of workers exposed to PAHs published in 2007, Bosetti and colleagues $^{84}$ reported a pooled relative risk of 1.51 (95\% CI 1.28-1.78) for roofers, 2.58 (95\% CI 2.28-2.92) for coal gasification, 1.58 (95\% CI 1.47-1.69) for coke production, and 1.40 (95\% CI 1.31-1.49) for iron and steel foundries. A non-statistically significant pooled relative risk of 1.03 (95\% CI 0.95-1.11) was found for aluminum production workers. For additional information on the lung cancer risk posed by coal gasification, coke production, iron and steel founding, and aluminum production, see http://monographs.iarc.fr/ENG/ Monographs/vol100F/index.php.

\section{Painting}

The increased use of water-based paints and the intentional reduction of some of the toxic agents in paints, such as benzene, phthalates, lead oxides, and chromates, have reduced the risk of adverse health outcomes related to painting. Nonetheless, painters continue to have the potential for exposure to hundreds of hazardous chemicals (eg, dichloromethane, diisocyanates, amines, esters, chromates, nickel, ketones). ${ }^{85}$ For additional details, see http:// monographs.iarc.fr/ENG/Monographs/vol100F/mono100F-35.pdf.

More than 50 epidemiologic studies (ie, cohort and case-control) were published between 1951 and 2010 that overall demonstrate a relatively consistent increased risk for painters. A 2010 meta-analysis based on census reports, and case-control and cohort studies published through $2008,{ }^{86}$ reported a summary risk estimate for lung cancer among painters of 1.29 (95\% CI 1.10-1.51) for case-control studies and 1.22 (95\% CI 1.16-1.29) and 1.36 (95\% CI 1.34-1.41) for lung cancer incidence and mortality studies, respectively. A second large meta-analysis published in $2010,{ }^{87}$ which included more than 11,000 incident lung cancer cases or deaths among painters, reported a summary risk estimate for lung cancer of 1.35 (95\% CI 1.29-1.41) and 1.35 (95\% CI 1.21-1.51) after controlling for smoking. In addition, the exposure-response relationship suggested the risk increased with duration of employment. For additional information on the lung cancer risk associated with painting as a profession, see http://monographs.iarc.fr/ENG/Monographs/vol100F/mono100F-35.pdf.

\section{Rubber Manufacturing Industry}

Rubber production workers are exposed to fumes with a complex chemical composition generated during the heating and curing of rubber compounds. The cyclohexane-soluble fraction of fumes often serves as an indicator to assess total particulate fume contamination. ${ }^{88}$ In addition, high concentrations of nitrosamines are formed in rubber manufacturing during the vulcanizing process. ${ }^{89,90}$ Furthermore, other likely exposures include carbon black, asbestos-contaminatedtalc, solvents, phthalates, and PAHs. ${ }^{88,91}$

The 2009 IARC work group concluded that there was sufficient evidence in humans for the carcinogenicity of occupational exposures in the rubber-manufacturing industry based in large part on retrospective cohort mortality studies that reported increased lung cancer risks among rubber workers involved with mixing and milling, vulcanization, tire-curing departments, and in cohorts of workers exposed to high concentrations of fumes and/or solvents. ${ }^{88}$ Overall, there has been a high degree of heterogeneity of findings for both cohort and case-control studies. A 2006 meta-analysis that included 24 cohort studies of workers in the synthetic rubber-producing industry ${ }^{92}$ reported a summary Standardized Mortality Ratio (SMR) of 1.05 (95\% CI 0.94-1.18). Several other recent cohort studies of rubber workers performed in Germany, the United Kingdom, and Italy reported similar findings. ${ }^{93-95}$ It is unknown to what extent these recent studies were affected by the Healthy Worker Effect. For additional information on the lung cancer risk associated with rubber manufacturing, see http://monographs.iarc.fr/ENG/Monographs/vol100F/mono100F-36.pdf. 


\section{IARC GROUP 1 LUNG CARCINOGENS: METALS}

\section{Arsenic and Inorganic Arsenic Compounds}

Arsenic, a chemical element classified as a metalloid, is both an environmental and occupational lung carcinogen. The most common forms of arsenic in the environment are arsenite and arsenate. Arsenic compounds linked with carbon and hydrogen are considered organic; those combined with oxygen, chlorine, sulfur, and so forth, but without carbon are considered inorganic. Occupational exposures occur primarily among workers who breathe dust from lead, gold, and copper ore mines and smelters. Another potential source of exposure that has diminished in the past 10 years owing to declining use, occurred during the production and application of arsenical insecticides (eg, lead arsenate, calcium arsenate), herbicides, and wood preservatives. Arsenic is also used ${ }^{96}$ in the production of the following products or processes:

- Glassware production

- Pigment reduction

- Solders

- Semiconductors

- Ceramics

- Fireworks

- Textiles

Sources of airborne exposures include emissions from smelting of metals (eg, nickel copper smelters), from insecticide/herbicide application, and natural releases from volcanic sources. A significant source of human exposure occurs from consumption of fish and seafood. ${ }^{96}$ Over the past 10 years, a major source of environmental exposure of concern with regard to lung cancer is drinking water containing arsenic from groundwater sources.

In addition to studies of historical exposure from pesticidal and pharmaceutical uses, the 2009 IARC work group reviewed a large body of findings from 2 primary routes of arsenic exposure: occupational groups who had exposure to a mixture of inorganic arsenic compounds in contaminated air and nonoccupational studies of individuals who ingested arsenic (ie, arsenite and arsenate) in drinking water over a protracted period. The IARC concluded that the cohort and nested case-control studies provided fairly consistent exposure-response evidence that arsenic exposure via inhalation increases (eg, Standardized Mortality Ratio (SMR) range 2-3) lung cancer risk ${ }^{97}$; however, the quality of the exposure data for inorganic arsenic did not allow a separation of the risk based on a particular arsenic species. In a study of more than 8000 Montana copper smelters employed through 1989 , Lubin and colleagues ${ }^{98}$ reported a linear exposure-response between cumulative estimated inhaled inorganic arsenic and respiratory cancer mortality. The person-year-weighted mean cumulative arsenic exposure was $3.7 \mathrm{mg} / \mathrm{m}^{3}$-years with a reported SMR for respiratory cancer of 1.56 (95\% CI 1.4-1.7). The investigators also noted that "inhalation of higher concentrations of arsenic over shorter durations was more deleterious than inhalation of lower concentrations over longer durations."

The IARC detailed the results of numerous ecologic studies and case-control studies performed in Argentina, Bangladesh, Chile, and Taiwan that examined the associations between higher concentrations (eg, >100 $\mu \mathrm{g} / \mathrm{L}$ ) of arsenic in drinking water and lung cancer. Overall, the ecologic (eg, studies that use aggregate or summary data to assess both exposure and often adverse health outcomes) studies reported significantly increased risks with increasing estimated levels of arsenic exposure.$^{97} \mathrm{~A}$ case-control study performed by 
Ferreccio and colleagues ${ }^{99}$ reported ORs of 1.0, 1.6 (95\% CI 0.5-5.3), 3.9 (95\% CI 1.212.3), 5.2 (95\% CI 2.3-11.7), and 8.9 (95\% CI 4.0-19.6) for long-term exposure to ingested waterborne arsenic concentrations of less than 10,10 to 29,30 to 49,50 to 199 , and 200 to $400 \mu \mathrm{g} / \mathrm{L}$, respectively. The investigators also observed a synergistic (ie, greater than additive) effect between waterborne arsenic concentrations and smoking.

Studies examining the association between drinking water with lower concentrations of arsenic and lung cancer are less supportive of an association between ingested arsenic in drinking water and lung cancer. It is not known if the lack of evidence of an association below $100 \mu \mathrm{g} / \mathrm{L}$ is the result of a threshold effect or an attenuation of the observed risk from nondifferential exposure misclassification. ${ }^{100}$ Because of the large population at risk from exposure to arsenic in their drinking water, arsenic exposure may represent a substantial public health problem if a risk threshold does not exist. For additional information on the lung cancer risk posed by exposure to arsenic and arsenic compounds, see http:// monographs.iarc.fr/ENG/Monographs/vol100C/mono100C-6.pdf.

\section{Beryllium and Beryllium Compounds}

Beryllium is a silver-gray metallic divalent element that occurs naturally in the earth's crust. ${ }^{101,102}$ Airborne concentrations are generally low and originate primarily form windblown dusts. Higher atmospheric concentrations of beryllium have been detected in the vicinity of coal-generating plants, municipal waste incineration, and beryllium ore processing and production plants, ${ }^{101,102}$ and between 1959 and 1970 near the burning of solid rocket fuel. ${ }^{103}$ The United States, China, and Kazakhstan are the only countries currently involved in the industrial-scale extraction of beryllium. ${ }^{104}$

A large proportion of the beryllium manufactured is in the form of copper-beryllium alloys. High rigidity, thermal stability, thermal conductivity, low density, and antispark properties make beryllium an important material ${ }^{101-103}$ for numerous products, including the following:

- Aircraft

- Missiles

- Space vehicles

- Communication satellites

- Automotive (eg, antilock breaking systems)

- Consumer products (eg, camera shutters)

- Energy and electrical

- Tools

- $\quad$ Sporting goods (eg, golf clubs)

- Electronics, biomedical (eg, dental braces and bridges, $\mathrm{x}$-ray tube windows)

- Jewelry

- Scrap recovery and recycling

- Defense

- Nuclear industries

Kreiss and colleagues ${ }^{105}$ estimated that more than 134,000 US workers have been exposed to beryllium. Beryllium that is inhaled may slowly dissolve in the lungs and move into the 
bloodstream. Some beryllium may be expectorated from the lungs and swallowed, although once engulfed by macrophages the particles have clearance rate half-times of hundreds to thousands of days. ${ }^{106,107}$ The IARC has classified beryllium as a Group 1 known human carcinogen since 1981. The IARC based its 1993 review of the lung carcinogenicity of beryllium primarily on studies from US Beryllium Case Registry cases and from the findings of a cohort study of 9225 workers employed at 7 beryllium-processing plants. ${ }^{108}$ In the 2009 IARC working group assessment of the lung carcinogenicity of beryllium, ${ }^{102}$ the work group references a nested case-control study performed by Schubauer-Berigan and colleagues ${ }^{109}$ that included 142 lung cancer cases each matched to 5 controls as supporting the lung carcinogenicity of beryllium. The investigators reported a significant relationship between average, but not cumulative, beryllium exposure and lung cancer risk after adjusting for birth year. Even though the study was criticized for methodological issues related to selection of controls, ${ }^{110}$ the IARC working group noted that the criticisms did not undermine their confidence in the findings referencing several publications that supported the methodology used in the analyses. ${ }^{102}$

Two subsequent studies by Schubauer-Berigan and colleagues ${ }^{111,112}$ published since the IARC's 2009 review provide further support for the lung carcinogenicity of beryllium. The first study ${ }^{111}$ extended the mortality follow-up (1940 through 2005) for 9199 workers from the 7 beryllium-processing plants. The study reported elevated lung cancer rates as compared with the US population (SMR 1.17, 95\% CI 1.08-1.28) and intracohort analysis found that workers with maximum beryllium exposure of $10 \mu \mathrm{g} / \mathrm{m}^{3}$ or higher had higher rates of lung cancer. Positive trends with cumulative beryllium exposure were observed for lung cancer $(P=.01)$ when short-term workers were excluded. The second study performed by Schubauer-Berigan and colleagues ${ }^{112}$ examined the shape of exposure-response associations between various exposure metrics and lung cancer, while adjusting for potential confounders (ie, race, plant, professional and short-term work status, and exposure to other lung carcinogens). The investigators reported positive associations between lung cancer and mean $(P<.0001)$ and maximum $(P<.0001)$ beryllium exposure with adjustment for age, birth cohort, and plant, as well as positive associations for cumulative $(P=.0017)$ beryllium exposure with adjustment for the previous factors plus short-term work status and exposure to asbestos.

Despite IARC's listing of beryllium as a Group 1 carcinogen, some researchers continue to reject the validity of the science on which the IARC based their decision, as well as the validity of the findings from the recent studies by Schubauer-Berigan and colleagues. ${ }^{111,112}$ In a review of epidemiologic data, supported by an unrestricted grant from Materion Brush, Inc, Boffetta and colleagues ${ }^{113}$ assert that most epidemiologic studies examining the association between beryllium exposure and lung cancer have likely failed to adequately address confounding by smoking and other occupational and lifestyle factors, claiming, "Overall, the available evidence does not support a conclusion that a causal association has been established between occupational exposure to beryllium and the risk of cancer." For additional information on the lung cancer risk posed by exposure to beryllium and beryllium compounds, see http://monographs.iarc.fr/ENG/Monographs/vol100C/mono100C-7.pdf.

\section{Cadmium and Cadmium Compounds}

Cadmium is a soft, bluish-white metal recovered as a by-product of zinc mining and refining. The zinc-to-cadmium ratios in most zinc ores range from 200:1 to 400:1. ${ }^{114}$ Cadmium use has decreased over time, except with its use in nickel-cadmium batteries, "silver solder" containing cadmium, and cadmium-telluride solar panels. These declines have come about because of its toxicity, the resulting regulations, and alternate technologies. ${ }^{115}$ This decrease in consumption was offset by the increased demand for 
cadmium in nickel-cadmium batteries, which accounted for $81 \%$ of the cadmium used as of 2006 in the United States. ${ }^{114}$

Environmental exposures to cadmium are primarily the result of volcano emissions, fossil fuel and wood combustion, forest fires, phosphate fertilizers, iron and steel production emissions, cement production and use, releases from phosphoric acid processes, smelting of nonferrous metals production, and municipal solid waste incineration. ${ }^{96}$ In addition, cigarettes contain varying concentrations of cadmium (in the microgram level) and approximately $10 \%$ of the cadmium is inhaled when a cigarette is smoked. ${ }^{115}$

The primary route of cadmium exposure in work areas is via the respiratory tract. The highest potential for occupational exposures occurs during the following work processes $^{115,116 \text { : }}$

- Welding or remelting cadmium-coated steel

- Smelting zinc and lead ores

- Work involving solders containing cadmium

- Battery production

- Pigment production

- Plastics production

- Processing, producing, and handling cadmium powders

In 2010, Alaska, Idaho, Missouri, and Tennessee produced zinc concentrate containing cadmium; cadmium metal was produced at a primary electrolytic zinc refinery at the Clarksville refinery in Tennessee and at secondary smelters in Ohio and Pennsylvania. ${ }^{117}$

Cohort epidemiologic studies of workers in the nickel alloy, nickel smelting, and nickelcadmium battery operations that were performed primarily between 1976 and 1998, as well as findings from a prospective population-based study in a cadmium-contaminated area in Belgium, formed the basis for the IARC's decision to classify cadmium and cadmium compounds as Group 1 carcinogens. ${ }^{118}$ The 2009 IARC working group noted that interpretation of findings from cohorts exposed are limited by small numbers of workers with high long-term exposures, a scarcity of cadmium exposure data, ability to compare exposure gradients between studies, and difficulty accounting for possible confounding by smoking. Among studies published since the IARC's 2009 review, Beveridge and colleagues ${ }^{119}$ reported an increased OR of 4.7 (95\% CI 1.5-14.3) only among former or nonsmokers with exposure to cadmium in 2 population-based case control studies in Montreal. Cadmium exposure did not produce an observable increased risk among smokers, however. Park and colleagues ${ }^{120}$ recently reported findings from a reanalysis of cadmium smelter workers that incorporated a retrospective exposure assessment for arsenic (As), updated mortality information for 1940 to 2002, a revised cadmium exposure matrix, and improved work history information. The investigators reported an increased lung cancer risk from airborne cadmium exposure independent of arsenic exposure (SMR $=3.2$ for $10 \mathrm{mg}$ year $/ \mathrm{m}^{3}$ cadmium, $P=.012$ ). For additional information on the lung cancer risk posed by exposure to cadmium and cadmium compounds, see http://monographs.iarc.fr/ENG/ Monographs/vol100C/mono100C-8.pdf.

\section{Chromium (VI) Compounds}

Chromium is the 21 st most abundant element in the earth's crust, occurring mainly in a trivalent state; however, hexavalent chromium (chromium VI) compounds are classified as Group 1 lung carcinogens and are produced primarily from industrial processes. OSHA 
classifies chromium (VI) compounds by their water solubility, specifically as follows: water insoluble (solubility $<0.01 \mathrm{~g} / \mathrm{L}$ ), slightly soluble (solubility $0.01 \mathrm{~g} / \mathrm{L}-500 \mathrm{~g} / \mathrm{L}$ ), and highly water soluble (solubility $2500 \mathrm{~g} / \mathrm{L}$ ). ${ }^{121}$ Exposure to chromium (VI) trioxide results in damage to the nasal mucosa and possible perforation of the nasal septum, whereas exposure to insoluble chromium (VI) compounds results in damage to the lower respiratory tract. ${ }^{122}$

The Agency for Toxic Substances and Disease Registry reports that about 9000 tons of chromium (VI) are released to the air each year in the United States. ${ }^{122}$ The potential for airborne environmental exposure to chromium (VI) compounds is higher for individuals living near anthropogenic sources of chromium production. ${ }^{122}$ Although studies based on aggregate measures of exposure and lung cancer outcome (ie, ecologic studies) have been published suggesting an association between environmental exposure to chromium exposure and lung cancer, these types of studies are reserved for hypothesis generating rather than assessing risk. ${ }^{123}$

Based on a 2006 OSHA contractor's report, ${ }^{124}$ the following US industries with the highest number of workers exposed to chromium (VI) include:

- Welding

- Painting

- Electroplating

- Steel mills

- Iron and steel foundries

- Paint and coating production

- Plastic colorant production and use

- Chromium catalyst production

- Chromate chemical production

- Plating mixture production

- Printing ink production

- Chromium metal producers

- Chromate pigment production

- Chromated copper arsenate production

The IARC concluded from a review of more than 25 cohort studies published between 1952 and 2006 that there was sufficient evidence in humans for the lung carcinogenicity of chromium (VI) compounds, especially for highly exposed workers in the chromate production, chromate pigment production, and chromium-plating industries. ${ }^{125}$ The 2009 IARC working group pointed out that because of the mixed exposures workers received and the increased lung cancer risk observed in diverse industries that exposed workers to varying chromium (VI) compounds, the IARC recommended that the broad category of chromium (VI) be listed a Group 1 carcinogen.

Studies of workers with lower estimated exposures of chromium (VI) that have been published since 2000 have produced mixed results. For example, a recent pooled analysis of 2 case-control studies of Montreal workers exposed to lower estimated concentrations (ie, exposed/unexposed) of chromium (VI) reported ORs of 2.4 (95\% CI 1.2-4.8) for nonsmoking, chromium (VI)-exposed workers versus 1.0 (95\% CI 0.7-1.3) for chromium (VI)-exposed workers who smoked. ${ }^{119,125}$ It should be noted that the results for the 
nonsmoking workers were based on findings from only 46 controls and 12 cases. For additional information on the lung cancer risk posed by exposure to chromium (VI) compounds, see http://monographs.iarc.fr/ENG/Monographs/vol100C/mono100C-9.pdf.

\section{Nickel Compounds}

Nickel is a silvery white metal that occurs naturally, as the 24th most abundant element, in the earth's crust, generally accompanying sulfide and silica-oxides ores. The mining of these ores, which contain less than 3\% nickel, occurred in the United States from the late 1950s to 1998. ${ }^{126-128}$ New US nickel-mining sites have been developed in Minnesota and Michigan. The potential for low-level atmospheric nickel exposure arises from natural sources (eg, windblown dust, volcanoes, forest, and wildfires) and anthropogenic activities (eg, mining, refining, smelting, manufacture of nickel-containing alloys and stainless steel, fossil fuel combustion, waste incineration). ${ }^{129}$ The EPA estimates that in 2007, 1027 facilities released 30.5 million pounds of nickel compounds ${ }^{127}$; however, atmospheric concentrations of nickel compounds in the United States are reported to be 100,000 to 1 million times lower than the concentrations reported to increase cancer rates. ${ }^{130}$ Although studies have shown an association between aggregate measures of environmental exposure to nickel compounds and lung cancer, these types of studies (ie, ecologic studies) are generally reserved for hypothesis generating rather than testing. ${ }^{123}$

Occupations that have the potential for exposure to nickel compounds include ${ }^{126-130}$ the following:

- Battery makers, storage

- Catalyst workers

- Ceramic makers

- Chemists

- Disinfectant makers

- Dyers

- Electroplaters

- Enamellers

- Ink makers

- Magnet makers

- Nickel-alloy makers

- Mold makers

- Nickel miners

- Nickel refiners

- Nickel smelters

- Nickel workers

- Organic chemical synthesizers

- Paint makers

- Petroleum refinery workers

- $\quad$ Stainless-steel makers 
- Textile dyers

- Vacuum tube makers

- Varnish makers

- Welders

The primary evidence demonstrating the human lung carcinogenicity of nickel compounds and nickel metal is based on epidemiologic findings from nickel refinery and nickel smelter workers. The 2009 IARC working group concluded, ${ }^{129}$ after a detailed review of pertinent epidemiologic studies, that strong evidence for the carcinogenicity of nickel compounds exists for nickel chloride, ${ }^{131}$ nickel sulfate, water-soluble nickel compounds in general, ${ }^{131,132}$ insoluble nickel compounds, nickel oxides, ${ }^{131,133}$ nickel sulfides, ${ }^{134}$ and mostly insoluble nickel compounds. ${ }^{133}$

The investigators ${ }^{135}$ of a study funded by Nickel Producers Environmental Research Association contend that, in addition to lack of adequate control for confounding, the epidemiologic studies focusing on soluble nickel compounds cannot differentiate between nickel compounds, and therefore some of the increased risk attributed to soluble nickel compounds may be from other nickel species. However, the IARC ${ }^{129}$ cites the studies of Norwegian refinery workers ${ }^{131,132,136}$ to support the basis for the human lung carcinogenicity of soluble nickel because of the availability of cigarette smoking data and the adjustments that were performed to reduce potential confounding. The IARC's ${ }^{129} 2009$ evaluation of nickel as a lung carcinogen concludes that there is "sufficient evidence in humans for the carcinogenicity of mixtures that include nickel compounds and nickel metal. The evidence is strongest for soluble nickel compounds; there is also independent evidence for the carcinogenicity of oxidic and sulfidic nickel compounds."

The IARC's position is further supported by a recent study by Grimsrud and Andersen ${ }^{137}$ who assert that the claimed absence of nickel-related respiratory cancer among electrolysis workers resulted from "an arbitrary overemphasis of biased and inconclusive findings" by some researchers. ${ }^{135}$ Another recent case-control study performed in Italy ${ }^{138}$ that used a lifetime job exposure matrix, estimated an OR of 1.18 (95\% CI 0.90-1.53) among workers with relatively low exposures of combined nickel-chromium exposure (eg, metal mechanics). For additional information on the lung cancer risk posed by exposure to nickel compounds, see http://monographs.iarc.fr/ENG/Monographs/vol100C/mono100C-10.pdf.

\section{IARC GROUP 1 LUNG CARCINOGENS: DUST AND FIBERS}

\section{Asbestos (All Forms)}

Asbestos is a naturally occurring fibrous silicate mineral that exists in 2 forms: serpentine (ie, chrysotile) and amphibole (ie, actinolite, amosite, anthophyllite, crocidolite, and tremolite). Chrysotile, anthophyllite, amosite, and crocidolite asbestos have been used commercially. ${ }^{139}$ Widespread application of asbestos materials in various settings in the United States did not occur until the early 1930s; however, by 1980, the construction industry accounted for more than two-thirds of the total asbestos demand.

A 1989 EPA ban on most asbestos-containing products was overturned in 1991 by a federal court; however, a ban continues on several items (eg, flooring felt, roll board, and certain types of specialty paper), as well as for products that have not historically contained asbestos, otherwise referred to as "new uses" of asbestos. ${ }^{140}$ Asbestos is not currently mined in the United States, and the use of asbestos in 2011 was similar to the level (ie, 1000 ton/y) of use in $1909 .{ }^{141}$ Most of the asbestos currently used in the United States, which is primarily chrysotile asbestos, is imported from Canada. ${ }^{141}$ 
Because of the past widespread use of asbestos-containing products, the potential for exposure is widespread, but nonetheless has decreased each year since the partial ban. The primary sources of exposure for members of the general public include releases of asbestos (eg, friable asbestos-containing building materials and insulation) from older buildings, brake linings, demolition of older buildings, living near asbestos-containing waste sites or asbestos-related industries, asbestos-contaminated vermiculite, exposure to poorly contained asbestos removal operations, and exposure to talc containing asbestiform fibers. ${ }^{142,143}$ "Bystander exposure" to asbestos fibers can also take place by contact with asbestos workers or their clothes.

Occupational exposures in the past were much more prevalent and included ${ }^{142-144}$ the following:

- Asbestos mining and processing operations

- Talc mining and processing (talc containing asbestiform fibers)

- Asbestos insulation

- Textile work

- The manufacture of asbestos-containing products

- $\quad$ Ship building

- Construction

- Numerous other industries

Occupational exposures still occur among workers who work with asbestos-containing end products, ${ }^{142-144}$ including the following occupations:

- Asbestos insulation workers

- Automotive repair and maintenance workers

- Building maintenance workers

- Building demolition workers and abatement workers (eg, materials: roof shingles, drywall, flooring, cement, fireproofing, insulation)

The 3 lung-specific adverse health outcomes associated with exposure to asbestos are asbestosis, lung cancer, and mesothelioma (which can be of the pleura as well as the peritoneum, but is not further considered in this review of lung cancer). A long-standing controversy not addressed in a substantive manner by the IARC ${ }^{137}$ is whether the risk of lung cancer is associated with asbestos exposure alone and/or asbestosis. ${ }^{14,143}$ The 2009 IARC working group concluded that all forms of asbestos cause lung cancer, ${ }^{144}$ however, while acknowledging that controversies remain regarding the potency differences for fibers of different types (eg, low potency of chrysotile versus high potency of amphiboles) ${ }^{145-147}$ and dimensions (eg, lower potency of shorter and wider fibers versus higher potency of thinner and longer fibers). ${ }^{148,149}$

The 2009 IARC working group indicated that some of the heterogeneity in findings between studies may not be related to differences in potency for different fiber types, but rather differences in rigor of exposure assessment. The investigators of a meta-analysis published in 2011 reported $^{150}$ that studies with higher-quality asbestos exposure data produced higher meta-estimates of the lung cancer risk per unit of exposure and that discerning potency differences between chrysotile versus amphibole asbestos-exposed cohorts was more challenging when the meta-analyses are limited to a smaller number of studies with questionable exposure assessment methods. 
Nonetheless, several studies ${ }^{151,152}$ reported an increased risk for lung cancer associated with chrysotile asbestos exposure. In a retrospective cohort study of 5770 textile workers in North Carolina, Loomis and colleagues ${ }^{153}$ reported an SMR of 1.96 (95\% CI 1.7-2.2) for lung cancer. In addition, a 2008 retrospective cohort study of 3072 workers at a South Carolina textile plant reported that lung cancer was most strongly associated with exposure to thin $(<0.25 \mu \mathrm{m})$ and longer $(>10 \mu \mathrm{m})$ fibers. A recent pooled analysis ${ }^{154}$ of $3717 \mathrm{men}$ and 2419 women employed at any of the 4 textile mills in North or South Carolina before 1973 reported a pooled relative rate for lung cancer of 1.11 (95\% CI 1.06-1.16) when comparing exposures at $100 \mathrm{f}-\mathrm{y} / \mathrm{mL}$ to $0 \mathrm{f}-\mathrm{y} / \mathrm{mL}$. A subsequent analysis ${ }^{155}$ found that whereas lung cancer mortality was associated with particles of any size, exposure to longer (ie, $>5-10 \mu \mathrm{m}$ ) and thinner $(<0.25 \mu \mathrm{m})$ fibers presented a greater risk. For additional information on the lung cancer risk posed by exposure to asbestos, see http://monographs.iarc.fr/ENG/ Monographs/vol100C/mono100C-11.pdf.

\section{Silica Dust, Crystalline, in the Form of Quartz or Cristobalite}

Silicon is the second most common element in the Earth's crust. Two allotropes of silicon, amorphous and crystalline, exist at room temperature. The compound silica, also known as silicon dioxide $\left(\mathrm{SiO}_{2}\right)$, makes up more than $25 \%$ of the Earth's crust. Amorphous silica usually occurs as a brown powder as compared with the metallic luster and a grayish color of crystalline silica. ${ }^{156}$ Crystalline silica exists as quartz, cristobalite, tridymite, and 4 other very rare forms (ie, keatite, coesite, stishovite, and moganite). ${ }^{157}$ Quartz is the most common form of crystalline silica and the primary component of sand and of dust in the air. ${ }^{156}$

Environmental exposures to silica can arise from natural (eg, forest fires, volcanic eruptions, wind erosion) and anthropogenic activities (eg, construction, gravel roads, demolition, quarrying, mining, and farming activities-tilling). The potential for occupational exposure to silica is widespread. Potential occupational exposures to silica include a wide variety of occupations and industries, ${ }^{157-159}$ including the following:

- Oil and gas extraction

- Bituminous coal and lignite mining

- Mining and quarrying of nonmetallic minerals (except most fuels) including silica sand mining

- Hydraulic fracturing for natural gas development (Fig. 4)

- Metal mining

- Masonry, stonework, tile setting, and plastering

- Services to dwellings and other buildings

- Concrete, gypsum, and plaster products

- Roofing and sheet metal work

- Construction (eg, bridge, tunnel, and elevated highway)

- Agricultural activities

- Wrecking and demolition activities

- Medical and dental laboratories work

- Foundry work (ferrous and nonferrous)

- Vitreous enameling 
- Glass manufacturing

- Manufacturing of soaps and detergents

- Shipyard work

- Railroads

- Automotive repair shops

- Production of pottery and related items

The 2009 IARC working group's reaffirmation of the lung carcinogenicity of silica focused on the epidemiologic findings from 5 primary occupational settings: ceramics, diatomaceous earth, ore mining, quarries, and sand and gravel. ${ }^{159}$ Among these industries, the IARC assumed sand and gravel operations, quarries, and diatomaceous earth facilities had the least potential for confounding and reported that studies with quantitative exposures generally report increased lung cancer rates with increasing exposure to crystalline silica. However, the IARC indicates the strongest evidence supporting the lung carcinogenicity of crystalline silica was from the pooled epidemiologic studies ${ }^{160,161}$ that revealed a clear exposureresponse relationship and an overall increased lung cancer risk for the meta-analyses from a diverse number of industries. ${ }^{162,163}$ Debate continues that the inflammation caused by crystalline silica exposure, and perhaps the resulting silicosis, is the driving force for the development of cancer. ${ }^{162,164-166}$ For additional information on the lung cancer risk posed by exposure to silica dust, crystalline, in the form of quartz or cristobalite, see http:// monographs.iarc.fr/ENG/Monographs/PDFs/index.php.

\section{IARC GROUP 2 LUNG CARCINOGENS}

Group 2-listed human lung carcinogens include the following:

- Acid mists, strong inorganic

- Art glass, glass containers, and pressed ware (manufacture of)

- Biomass fuel (primarily wood) indoor emissions from household combustion of

- Bitumens, oxidized, and their emissions during roofing

- Bitumens, hard, and their emissions during mastic asphalt work

- Carbon electrode manufacture

- alpha-Chlorinated toluenes (benzal chloride, benzotrichloride, benzyl chloride) and benzoyl chloride (combined exposures)

- 2,3,7,8-tetrachlorodibenzo-para-dioxin

- Cobalt metal with tungsten carbide

- Creosotes

- Frying, emissions from high temperature

- Insecticides, nonarsenical (occupational exposures in spraying and application)

- Printing processes (occupational exposures in)

- Welding fumes

Scientific evidence is also mounting that other Group 2 human lung carcinogens ${ }^{167}$ should receive greater consideration as Group 1 carcinogens. Fortunately, several potential lung carcinogens (eg, welding; motor vehicle emissions; carbon-based nanoparticles; crystalline 
fibers other than asbestos; outdoor air pollution, including sulfur oxides, nitrogen oxides, ozone, and dusts; ultrafine particles) are listed as priority agents for future review. ${ }^{168}$

\section{SUMMARY}

The IARC's updated assessments, published in 2012 as Volume $100 \mathrm{C}$ through F of the IARC Monographs, provide a long overdue resource for consensus opinions on the carcinogenic potential of various agents. Unfortunately, many of the studies reviewed by IARC, which attempted to identify whether or not a causal association existed between various exposures and lung cancer, were often impeded by confounding from smoking and poor retrospective exposure assessment. As pointed out in the President's Cancer Panel's 2010 report, ${ }^{16}$ research on environmental and occupational causes of cancer have been limited by low priority and inadequate funding. This is especially true for lung cancer research. The large percentage of lung cancer deaths caused by smoking often obscures the fact that nonsmoking-related lung cancer is 1 of the top 10 causes of cancer mortality and, in some cases (eg, medically related radiation exposures, radon), the attributable risk of the agent is increasing. The foregoing data also underscore that in the clinical assessment of lung cancer risk, ascertaining past occupational exposures as well clarifying selected environmental risks should hold an equal place to quantifying cumulative cigarette smoking in pack years.

\section{Acknowledgments}

Funding sources: Dr Field: NIOSH Grant T42 OH008491, NIEHS Grant P30 ES05605. Dr Withers: NIOSH Grant T42 OH008491.

\section{REFERENCES}

1. Howlader, N.; Noone, AM.; Krapcho, M., et al., editors. SEER cancer statistics review, 1975-2008. National Cancer Institute; Bethesda (MD): 2011. Available at: http://dccps.nci.nih.gov/ocs/ prevalence/prevalence.html

2. Siegel R, Naishadham D, Jemal A. Cancer statistics 2012. CA Cancer J Clin. 2011; 62(1):10-29. [PubMed: 22237781]

3. U.S. Center for Disease Control. Annual smoking-attributable mortality, years of potential life lost, and productivity losses-United States, 1997-2001. MMWR Morb Mortal Wkly Rep. 2005; 54:625-8. [PubMed: 15988406]

4. Thun MJ, Henley SJ, Burns D, et al. Lung cancer death rates in lifelong nonsmokers. J Natl Cancer Inst. 2006; 98:691-9. [PubMed: 16705123]

5. Sun S, Schiller JH, Gazdar AF. Lung cancer in never smokers-a different disease. Nat Rev Cancer. 2007; 7:778-90. [PubMed: 17882278]

6. Ferlay J, Shin H-R, Bray F, et al. Estimates of worldwide burden of cancer in 2008: GLOBOCAN 2008. Int J Cancer. 2010; 127(12):2893-917. [PubMed: 21351269]

7. Couraud S, Zalcman G, Milleron B, et al. Lung cancer in never smokers-a review. Eur J Cancer. 2012 Available at: http://dx.doi.org/10.1016/j.ejca.2012. 03.007.

8. Wakelee HA, Chang ET, Gomez SL, et al. Lung cancer incidence in never smokers. J Clin Oncol. 2007; 25(5):472-8. [PubMed: 17290054]

9. Blair A, Freeman LB. Lung cancer among nonsmokers. Epidemiology. 2006; 17(6):601-13. [PubMed: 17068413]

10. Subramanian J, Govindan R. Lung cancer in never smokers: a review. J Clin Oncol. 2007; 25(5): 561-70. [PubMed: 17290066]

11. Samet JM, Avila-Tang E, Boffetta P, et al. Lung cancer in never smokers: clinical epidemiology and environmental risk factors. Clin Cancer Res. 2009; 15(18):5626-45. [PubMed: 19755391]

12. Neuberger J, Field RW. Occupation and lung cancer in nonsmokers. Rev Environ Health. 2003; 18(4):251-67. [PubMed: 15025189] 
13. Spitz, MR.; Wu, X.; Wilkinson, A., et al. Cancer of the lung. In: Schottenfeld, D.; Fraumei, J., editors. Cancer epidemiology and prevention (third edition). Oxford University Press; New York, NY: 2006. p. 638-58.

14. Dela, Cruz CS.; Tanoue, LT.; Matthay, RA. Lung cancer: epidemiology, etiology, and prevention. Clin Chest Med. 2011; 32:605-44. [PubMed: 22054876]

15. Doll R, Peto R. The causes of cancer: quantitative estimates of avoidable risks of cancer in the United States today. J Natl Cancer Inst. 1981; 66:1191-308. [PubMed: 7017215]

16. President's cancer panel. Reducing environmental cancer risk: what we can do now. National Cancer Institute, National Institutes of Health, U.S. Department of Health and Human Services; Bethesda (MD): 2010. 2008-2009 annual report. Available at: http://deainfo.nci.nih.gov/advisory/ pcp/annualReports/pcp08-09rpt/PCP_Report_08-09_508.pdf [Accessed April 5, 2012]

17. Harvard Center for Cancer Prevention, Harvard School of Public Health. Harvard Report on Cancer Prevention. Vol. 1: human causes of cancer. Cancer Causes Control. 1996; 7(1):S3-4. Available at: http://www.hsph.harvard.edu/cancer/resources_materials/reports.index.htm. [PubMed: 9091058]

18. Doll R. Epidemiological evidence of the effects of behavior and the environment on the risk of human cancer. Recent Results Cancer Res. 1998; 154:3-21. [PubMed: 10026990]

19. Travis LB, Gospodarowicz M, Curtis RE, et al. Lung cancer following chemotherapy and radiotherapy for Hodgkin's disease. J Natl Cancer Inst. 2002; 94:182-92. [PubMed: 11830608]

20. Herbst RS, Heymach JV, Lippman SM. Lung cancer. N Engl J Med. 2008; 359(13):1367-80. [PubMed: 18815398]

21. El Ghissassi F, Baan R, Straif K, et al. A review of human carcinogens-part D: radiation. Lancet Oncol. 2009; 10(8):751-2. [PubMed: 19655431]

22. National Council on Radiation Protection and Measurement. Ionizing radiation exposure of the population of the United States. NCRP; Bethesda (MD): 2009. Report No. 160, Figure 1-1

23. IARC Monographs on the Evaluation of Carcinogenic Risks to Humans. A review of human carcinogens: Radiation. 2012; vol. 100D:341. Available at: http://monographs.iarc.fr/ENG/Mono graphs/vol100D/mono100D-9.pdf.

24. Zhou H, Randers-Pehrson G, Suzuki M, et al. Genotoxic damage in non-irradiated cells: contribution from the bystander effect. Radiat Prot Dosimetry. 2002; 99(1-4):227-32. [PubMed: 12194291]

25. National Research Council. Committee on the health risks of exposure to radon. National Academy Press; Washington, DC: 1999. Health effects of exposure to radon: BEIR VI.

26. Agricola, G. De Re Metallica. Dover Publications Inc; New York: 1950. p. 6381556[Hoover HC, Hoover LH]

27. Schefflers, CL. Abhandlung von der Gesundheit der Bergleute. Strossel; Chemnitz (Germany): 1770. p. 274

28. Hesse W. Das Vorkommen von primärem Lungenkrebs bei den Bergleuten der consortschaftlichen Gruben in Schneeberg. Archiv der Heilkunde. 1878; 19:160-2. [in German].

29. Harting FH, Hesse W. Der Lungenkrebs, die bergkrankheit in den schneeberger gruben. Viertel Gerichtl Med Oeff Sanitaetswes. 1879; 31:102-32. [in German].

30. Field, RW. Radon: an overview of health effects. In: Nriagu, JO., editor. Encyclopedia of environmental health. Vol. vol. 4. Elsevier; Burlington (Ontario): 2011. p. 745-53.

31. Lubin JH. Environmental factors in cancer: radon. Rev Environ Health. 2010; 25(1):33-8. [PubMed: 20429156]

32. International Commission on Radiological Protection. ICRP Publication 115: lung cancer risk from radon and progeny. Ann ICRP. 2012; 40(1) Available at:http://www.icrp.org/publication.asp? id=ICRP_Publica tion_115.

33. National Research Council, National Academy of Science. [Accessed April 20, 2012] Uranium mining in Virginia: scientific, technical, environmental, human health and safety, and regulatory aspects of uranium mining and processing in Virginia, Prepublication, 2011. Available at: http:// dels.nas.edu/Report/Uranium-Mining-Virginia-Scientific-Technical/13266 
34. Schubauer-Berigan MK, Daniels RD, Pinkerton LE. Radon exposure and mortality among white and American Indian uranium miners: an update of the Colorado Plateau cohort. Am J Epidemiol. 2009; 169(6):718-30. [PubMed: 19208723]

35. Rage E, Vacquier B, Blanchardon E, et al. Risk of lung cancer mortality in relation to lung doses among French uranium miners: follow-up 1956-1999. Radiat Res. 2012; 177(3):288-97. [PubMed: 22206233]

36. Lane RS, Frost SE, Howe GR, et al. Mortality (1950-1999) and cancer incidence (1969-1999) in the cohort of Eldorado uranium workers. Radiat Res. 2010; 174(6):773-85. [PubMed: 21128801]

37. Kreuzer M, Schnelzer M, Tschense A, et al. Cohort profile: the German uranium miners cohort study (WISMUT cohort), 1946-2003. Int J Epidemiol. 2010; 39(4):980-7. [PubMed: 19494089]

38. U.S. EPA. EPA assessment of risks from radon in homes. U.S. Environmental Protection Agency, Office of Radiation and Indoor Air; Washington, DC: 2003. Available at: http://www.epa.gov/ radiation/docs/assessment/402-r-03-003.pdf [Accessed April 15, 2012]

39. Lubin JH, Wang ZY, Boice JD, et al. Risk of lung cancer and residential radon in China: pooled results of two studies. Int J Cancer. 2004; 109(1):132-7. [PubMed: 14735479]

40. Darby S, Hill D, Deo H, et al. Residential radon and lung cancer-detailed results of a collaborative analysis of individual data on 7148 persons with lung cancer and 14208 persons without lung cancer from 13 epidemiologic studies in Europe. Scand J Work Environ Health. 2006; 32:1-84. [PubMed: 16538937]

41. Krewski D, Lubin JH, Zielinski JM, et al. Residential radon and risk of lung cancer-a combined analysis of 7 north American case-control studies. Epidemiology. 2005; 16(2):137-45. [PubMed: 15703527]

42. Field RW, Smith BJ, Lynch CF, et al. Intercomparison of radon exposure assessment methods: implications for residential radon risk assessment. J Expo Anal Environ Epidemiol. 2002; 12(3): 197-203. [PubMed: 12032816]

43. US Environmental Protection Agency. US Department of Health and Human Services. US Department of Agriculture. US Department of Defense. US Department of Energy. US Department of Housing and Urban Development. US Department of Interior. US Department Veterans Affairs. US General Services Administration. [Accessed April 3, 2012] Protecting people and families from radon, a federal action plan for saving lives. 2011. Available at: http:// www.epa.gov/radon/pdfs/Federal_Radon_Action_Plan.pdf

44. Agency for Toxic Substances and Disease Registry (ATSDR). Toxicological profile for plutonium. U.S. Department of Health and Human Services, Public Health Services; Atlanta (GA): 2010. Available at: http://www.atsdr.cdc.gov/toxprofiles/tp.asp?id=648\&tid=119 [Accessed April 15, 2012]

45. IARC, Ionizing radiation. Part 2: some internally deposited radionuclides. IARC Monogr Eval Carcinog Risks Hum. 2001; 78:1-559. [PubMed: 11421248]

46. Wing S, Richardson D, Wolf S, et al. Plutonium-related work and cause-specific mortality at the United States Department of Energy Hanford Site. Am J Ind Med. 2004; 45:153-64. [PubMed: 14748046]

47. Brown SC, Ruttenber AJ. Lung cancer and plutonium exposure in Rocky Flat waters. Radiat Res. 2005; 163:696-7. [PubMed: 16044497]

48. Brown SC, Schonbeck MF, McClure D, et al. Lung cancer and internal lung doses among plutonium workers at the Rocky Flats Plant: a case-control study. Am J Epidemiol. 2004; 160:163-72. [PubMed: 15234938]

49. Kreisheimer M, Sokolnikov ME, Koshurnikova NA, et al. Lung cancer mortality among nuclear workers of the Mayak facilities in the former Soviet Union. An updated analysis considering smoking as the main confounding factor. Radiat Environ Biophys. 2003; 42:129-35. [PubMed: 12851829]

50. Shilnikova NS, Preston DL, Ron E, et al. Cancer mortality risk among workers at the Mayak nuclear complex. Radiat Res. 2003; 159:787-98. [PubMed: 12751962]

51. Jacob V, Jacob P, Meckbach R, et al. Lung cancer in Mayak workers: interaction of smoking and plutonium exposure. Radiat Environ Biophys. 2005; 44:119-29. [PubMed: 16136318] 
52. Gilbert ES, Koshurnikova NA, Sokolnikov ME, et al. Lung cancer in Mayak workers. Radiat Res. 2004; 162:505-16. [PubMed: 15624305]

53. Sokolnikov ME, Gilbert ES, Preston DL, et al. Lung, liver and bone cancer mortality in Mayak workers. Int J Cancer. 2008; 123:905-11. [PubMed: 18528867]

54. UNSCEAR; United Nations Scientific Committee on the Effects of Atomic Radiation. Epidemiological studies of radiation and cancer. United Nations; New York: 2008. Report. Annex A.

55. National Research Council. Health risks from exposure to low levels of ionizing radiation: BEIR VII, Phase 2. National Academies Press; Washington, DC: 2006. Committee to Assess Health Risks from Exposure to Low Levels of Ionizing Radiation, Board on Radiation Effects.

56. Preston DL, Shimizu Y, Pierce DA, et al. Studies of mortality of atomic bomb survivors. Report 13: solid cancer and noncancer disease mortality: 1950-1997. Radiat Res. 2003; 160:381-407. [PubMed: 12968934]

57. Preston DL, Ron E, Tokuoka S, et al. Solid cancer incidence in atomic bomb survivors: 1958-1998. Radiat Res. 2007; 168:1-64. [PubMed: 17722996]

58. Gilbert ES, Stovall M, Gospodarowicz M, et al. Lung cancer after treatment for Hodgkin's disease: focus on radiation effects. Radiat Res. 2003; 159:161-73. [PubMed: 12537521]

59. Furukawa K, Preston DL, Lonn S, et al. Radiation and smoking effects on lung cancer incidence among atomic bomb survivors. Radiat Res. 2010; 174:72-82. [PubMed: 20681801]

60. HSDB. Hazardous Substances Data Bank. [Accessed April 20, 2012] National Library of Medicine. 2012. Available at: http://toxnet.nlm.nih.gov/cgi-bin/sis/search/f?./temp/ ZkJdFQ:1

61. NIOSH. National occupational exposure survey (1981-83). National Institute for Occupational Safety and Health; 1990. Available at: http://www.cdc.gov/noes/noes1/x6315sic.html [Accessed April 21, 2012]

62. Krieger RI, Dinoff TM, Zhang X. Octachlorodipropyl ether (s-2) mosquito coils are inadequately studied for residential use in Asia and illegal in the United States. Environ Health Perspect. 2003; 111(12):1439-42. [PubMed: 12948880]

63. Pauluhn J. Overview of inhalation exposure techniques: strengths and weaknesses. Exp Toxicol Pathol. 2005; 57(1):111-28. [PubMed: 16092719]

64. IARC Monographs on the Evaluation of Carcinogenic Risks to Humans. A review of human carcinogens: chemical agents and related occupations, bis(chloromethyl)ether. 2012; vol. 100F Available at: http://monographs.iarc.fr/ENG/Monographs/vol100F/mono100F-25.pdf.

65. Weiss W, Boucot KR. The respiratory effects of chloromethyl methyl ether. JAMA. 1975; 234:1139-42. [PubMed: 171460]

66. IARC Monographs on the Evaluation of Carcinogenic Risks to Humans. A review of human carcinogens: chemical agents and related occupations, sulfur mustard. 2012; vol. 100F Available at: http://monographs.iarc.fr/ENG/Monographs/vol100F/mono100F-30.pdf.

67. IARC. Genetic and related effects: an updating of selected IARC monographs from Volumes 1 to 42. IARC Monogr Eval Carcinog Risks Hum Suppl. 1987; 6:1-729. [PubMed: 3504843]

68. National Toxicology Program. Report on carcinogens, 2011, coal tars and coal-tar pitches. 12th edition. US Department of Health and Human Services, Public Health Service; p. 111-3.Available at: http://ntp.niehs.nih.gov/ntp/roc/twelfth/profiles/CoalTars.pdf [Accessed April 20, 2012]

69. IARC. Some non-heterocyclic polycyclic aromatic hydrocarbons and some related exposures. IARC Monogr Eval Carcinog Risks Hum. 2010; 92:1-853. Available at: http://monographs.iarc.fr/ ENG/Monographs/vo192/mono92.pdf. [PubMed: 21141735]

70. Boffetta PI, Burstyn T, Partanen H, et al. Cancer mortality among European asphalt workers: an international epidemiological study, results of the analysis based on job titles. Am J Ind Med. 2003; 43:18-27. [PubMed: 12494418]

71. Olsson A, Kromhout H, Agostini M, et al. A case-control study of lung cancer nested in a cohort of European asphalt workers. Environ Health Perspect. 2010; 118(10):1418-24. [PubMed: 20529766]

72. National Toxicology Program. Report on carcinogens, 2011, soots. 12th edition. US Department of Health and Human Services, Public Health Service; p. 379-80.Available at: http://

ntp.niehs.nih.gov/ntp/roc/twelfth/profiles/Soots.pdf [Accessed April 20, 2012] 
73. [Accessed April 15, 2012] National Chimney Sweep Guild. Available at: http://www.ncsg.org/

74. IARC Monographs on the Evaluation of Carcinogenic Risks to Humans. A review of human carcinogens: chemical agents and related occupations, soot, as found in occupational exposures of chimney-sweeps. 2012; vol. 100F Available at:http://monographs.iarc.fr/ENG/Monographs/ vol100F/mono100F-21.pdf.

75. Pukkala E, Martinsen JI, Lynge E, et al. Occupation and cancer-follow-up of 15 million people in five Nordic countries. Acta Oncol. 2009; 48:646-790. [PubMed: 19925375]

76. McDonald JD, Campen MJ, Harrod KS, et al. Engine-operating load influences diesel exhaust composition and cardiopulmonary and immune responses. Environ Health Perspect. 2011; 119(8): 1136-41. [PubMed: 21524982]

77. Pronk A, Coble J, Stewart PA. Occupational exposure to diesel exhaust: a literature review. J Expo Sci Environ Epidemiol. 2009; 19:443-57. [PubMed: 19277070]

78. IARC Monographs on the Evaluation of the Carcinogenic Risks of Chemicals to Humans. Diesel and Gasoline Engine Exhausts and Some Nitroarenes. Vol. Volume 46. International Agency for Research on Cancer; Lyon (France): 1989. Available at: http://monographs.iarc.fr/ENG/ Monographs/vol46/index.php [Accessed June 10, 2012]

79. International Agency for Research on Cancer. Diesel and gasoline engine exhausts and some nitroarenes. Vol. vol. 105. Lyon (France): 2012. Monographs on the Evaluation of Carcinogenic Risks to Humans; p. 5-12.Available at: http://www.iarc.fr/en/media-centre/iarcnews/2012/ mono105-info.php [Accessed June 12, 2012]

80. International Agency for Research on Cancer. [Accessed June 12, 2012] Diesel engine exhaust carcinogenic. Press release. Available at: http://press.iarc.fr/pr213_E.pdf

81. National Toxicology Program, Department of Health and Human Services. [Accessed June 12, 2012] Diesel exhaust particulates report on carcinogens. 12th Edition2011. Available at: http:// ntp.niehs.nih.gov/ntp/roc/twelfth/profiles/DieselExhaustParticulates.pdf

82. Silverman DT, Samanic CM, Lubin JH, et al. The diesel exhaust in miners study: a nested casecontrol study of lung cancer and diesel exhaust. J Natl Cancer Inst. 2012; 104(11):855-68. [PubMed: 22393209]

83. IARC Monographs on the Evaluation of Carcinogenic Risks to Humans. A review of human carcinogens: chemical agents and related occupations. 2012; vol. 100F Available at: http:// monographs.iarc.fr/ENG/Monographs/vol100F/index.php.

84. Bosetti C, Boffetta P, La Vecchia C. Occupational exposures to polycyclic aromatic hydrocarbons, and respiratory and urinary tract cancers: a quantitative review to 2005. Ann Oncol. 2007; 18:43146. [PubMed: 16936186]

85. IARC Monographs on the Evaluation of Carcinogenic Risks to Humans. A review of human carcinogens: chemical agents and related occupations, occupational exposure as a painter. 2012; vol. 100F Available at: http://monographs.iarc.fr/ENG/Monographs/vol100F/mono100F-35.pdf.

86. Bachand A, Mundt KA, Mundt DJ, et al. Meta-analyses of occupational exposure as a painter and lung and bladder cancer morbidity and mortality 1950-2008. Crit Rev Toxicol. 2010; 40(2):10125. [PubMed: 20085479]

87. Guha N, Merletti F, Steenland NK. Lung cancer risk in painters: a meta-analysis. Environ Health Perspect. 2010; 118:303-12. [PubMed: 20064777]

88. IARC Monographs on the Evaluation of Carcinogenic Risks to Humans. Occupational exposure in the rubber-manufacturing industry. 2012; vol. 100F Available at: http://monographs.iarc.fr/ENG/ Monographs/vol100F/mono100F-36.pdf.

89. Fajen JM, Carson GA, Rounbehler DP, et al. N-nitrosamines in the rubber and tire industry. Science. 1979; 205:1262-4. [PubMed: 472741]

90. International Agency for Research on Cancer. Printing processes, printing inks, carbon blacks and some nitro compounds. Vol. vol. 65. International Agency for Research on Cancer; Lyon (France): 1996.

91. Straif K, Keil U, Taeger D, et al. Exposure to nitrosamines, carbon black, asbestos, and talc and mortality from stomach, lung, and laryngeal cancer in a cohort of rubber workers. Am J Epidemiol. 2000; 152(4):297-306. [PubMed: 10968374] 
92. Alder N, Fenty J, Warren F, et al. Meta-analysis of mortality and cancer incidence among workers in the synthetic rubber-producing industry. Am J Epidemiol. 2006; 164:405-20. [PubMed: 16873420]

93. Taeger D, Weiland SK, Sun Y, et al. Cancer and non-cancer mortality in a cohort of recent entrants (1981-2000) to the German rubber industry. Occup Environ Med. 2007; 64:560-1. [PubMed: 17634250]

94. Dost A, Straughan J, Sorahan T. A cohort mortality and cancer incidence survey of recent entrants (1982-91) to the UK rubber industry: findings for 1983-2004. Occup Med (Lond). 2007; 57:18690. [PubMed: 17229717]

95. Pira E, Pelucchi C, Romano C. Mortality from cancer and other causes in an Italian cohort of male rubber tire workers. J Occup Environ Med. 2012; 54(3):345-9. [PubMed: 22361990]

96. Winder, C.; Stacey, NH., editors. Toxicity of metals, occupational toxicology. 2nd edition. CRC Press; Boca Raton (FL): 2004.

97. IARC Monographs on the Evaluation of Carcinogenic Risks to Humans. A review of human carcinogens: arsenic, metals, fibres, and dusts, arsenic and arsenic compounds. 2012; vol. 100C Available at:http://monographs.iarc.fr/ENG/Monographs/vol100C/mono100C-6.pdf.

98. Lubin JH, Moore LE, Fraumeni JF Jr, et al. Respiratory cancer and inhaled inorganic arsenic in copper smelter workers: a linear relationship with cumulative exposure that increases with concentration. Environ Health Perspect. 2008; 116(12):1661-5. [PubMed: 19079717] Epidemiology. 2000; 11(6):673-79. [PubMed: 11055628]

99. Ferreccio C, González C, Milosavjlevic V, et al. Lung cancer and arsenic concentrations in drinking water in Chile. Epidemiology. 2000; 11:673-9. [PubMed: 11055628]

100. Cantor KP, Lubin JH. Arsenic, internal cancers, and issues in inference from studies of low level exposures in human populations. Toxicol Appl Pharmacol. 2007; 222(3):252-7. [PubMed: 17382983]

101. McCleskey TM, Buchner V, Field RW, et al. Recent advances in understanding the biomolecular basis of chronic beryllium disease: a review. Rev Environ Health. 2009; 24(2):75-115. [PubMed: 19658317]

102. IARC Monographs on the Evaluation of Carcinogenic Risks to Humans. A review of human carcinogens: arsenic, metals, fibres, and dusts, beryllium and beryllium compounds. 2012; vol. 100C Available at:http://monographs.iarc.fr/ENG/Monographs/vol100C/mono100C-7.pdf.

103. United States General Accounting Office. [Accessed May 1, 2012] Report to Congressional Requesters, Occupational Safety and Health, Government responses to beryllium uses and risks, GAO/OCG-00-6. 2000. Available at:http://www.dau.mil/educdept/mm_dept_resources/reports/ Government-responses-to-Beryllium.pdf

104. Materion Brush Inc. [Accessed May 17, 2012] Sources of beryllium. Available at: http:// www.beryllium.com/sources-beryllium

105. Kreiss K, Day GA, Schuler CR. Beryllium: a modern industrial hazard. Annu Rev Public Health. 2007; 28:259-77. [PubMed: 17094767]

106. Agency for Toxic Substances and Disease Registry (ATSDR). Toxicological profile for beryllium. U.S. Department of Health and Human Services, Public Health Service; Atlanta (GA): 2002.

107. NIOSH, Comments of the National Institute for Occupational Safety and Health on the Department of Energy. Request for information on Chronic Beryllium Disease Prevention Program. Department of Health and Human Services, Centers for Disease Control and Prevention; Cincinnati (OH): 2011. Docket No. HS-RM-1 0-CBDPP RIN 1992-AA39, 2/22/11

108. IARC. Beryllium, cadmium, mercury, and exposures in the glass manufacturing industry. IARC Monogr Eval Carcinog Risks Hum. 1993; 58:1-415. [PubMed: 8022054]

109. Schubauer-Berigan MK, Deddens JA, Steenland K, et al. Adjustment for temporal confounders in a reanalysis of a case-control study of beryllium and lung cancer. Occup Environ Med. 2008; 65:379-83. [PubMed: 17890301]

110. Deubner DC, Roth HD. Rejoinder: progress in understanding the relationship between beryllium exposure and lung cancer. Epidemiology. 2009; 20:341-3. [PubMed: 19295436] 
111. Schubauer-Berigan MK, Couch JR, Petersen MR, et al. Cohort mortality study of workers at seven beryllium processing plants: update and associations with cumulative and maximum exposure. Occup Environ Med. 2011; 68(5):345-53. [PubMed: 20952555]

112. Schubauer-Berigan MK, Deddens JA, Couch JR, et al. Risk of lung cancer associated with quantitative beryllium exposure metrics within an occupational cohort. Occup Environ Med. 2011; 68(5):354-60. [PubMed: 21084327]

113. Boffetta P, Fryzek JP, Mandel J. Occupational exposure to beryllium and cancer risk: a review of the epidemiologic evidence. Crit Rev Toxicol. 2012; 42(2):107-18. [PubMed: 22276590]

114. USGS Commodity Report. [Accessed May 18, 2012] Cadmium. United States Geological Survey, Cadmium Statistics and Information. Available at: http://minerals.usgs.gov/minerals/ pubs/commodity/cadmium/

115. Agency for Toxic Substances and Disease Registry. US Department of Health and Human Services, Public Health Service. [Accessed April 25, 2012] Draft toxicological profile for cadmium. 2008. Available at: http://www.atsdr.cdc.gov/toxprofiles/tp5.pdf

116. National Toxicology Program. Department of Health and Human Services. [Accessed May 18, 2012] Report on carcinogens. Cadmium and cadmium compounds. 12th edition2011. CAS No. 7440-43-9 (Cadmium). Available at: http://ntp.niehs.nih.gov/ntp/roc/twelfth/profiles/ Cadmium.pdf

117. US Geological Survey. Minerals yearbook. US Department of the Interior; 2010. Cadmium, by Amy C. Tolcin. Available at: http://minerals.usgs.gov/minerals/pubs/commodity/cadmium/ myb1-2010-cadmi.pdf [Accessed May 18, 2012]

118. IARC Monographs on the Evaluation of Carcinogenic Risks to Humans. A review of human carcinogens: arsenic, metals, fibres, and dusts, beryllium and beryllium compounds, cadmium and cadmium compounds. 2012; vol. 100C Available at: http://monographs.iarc.fr/ENG/ Monographs/vol100C/mono100C-8.pdf.

119. Beveridge R, Pintos J, Parent ME, et al. Lung cancer risk associated with occupational exposure to nickel, chromium VI, and cadmium in two population-based case-control studies in Montreal. Am J Ind Med. 2010; 53(5):476-85. [PubMed: 20187007]

120. Park RM, Stayner LT, Petersen MR, et al. Cadmium and lung cancer mortality accounting for simultaneous arsenic exposure. Occup Environ Med. 2012; 69(5):303-9. [PubMed: 22271639]

121. Occupational Safety and Health Administration. Department of Labor. Occupational exposure to hexavalent chromium. Final rule. Fed Regist. 2006; 71:10099-385. [PubMed: 16528853]

122. Toxicological profile for chromium. U.S. Department of Health and Human Services, Public Health Service; Atlanta (GA): 2008. Agency for Toxic Substances and Disease Registry. (Draft for public comment)

123. Luo J, Hendryx M, Ducatman A. Association between six environmental chemicals and lung cancer incidence in the United States. J Environ Public Health. 2011; 2011 Article ID 463701. Available at: http://www.hindawi.com/journals/jeph/2011/463701/.

124. NIOSH. Hexavalent chromium, criteria document update, external review draft, occupational exposure to hexavalent chromium. Department of Health and Human Services, Centers for Disease Control and Prevention, National Institute for Occupational Safety and Health. 2008

125. IARC Monographs on the Evaluation of Carcinogenic Risks to Humans. A review of human carcinogens: arsenic, metals, fibres, and dusts, chromium (VI) compounds. 2012; vol. 100C Available at: http://monographs.iarc.fr/ENG/Monographs/vol100C/mono100C-9.pdf.

126. USGS. [Accessed April 25, 2012] 2009 Minerals yearbook, nickel (advance release). US Department of the Interior, US Geological Survey. Available at: http://minerals.usgs.gov/ minerals/pubs/commodity/nickel/myb1-2009-nicke.pdf

127. National Toxicology Program. Report on Carcinogens. 12th edition. US Department of Health and Human Services, Public Health Service; 2011. Nickel compounds and metallic nickel substance profiles. Available at: http://ntp.niehs.nih.gov/ntp/roc/twelfth/roc12.pdf [Accessed May 18, 2012]

128. Davis, JR. [Accessed April 25, 2012] Uses of nickel. ASM specialty handbook: nickel, cobalt, and their alloys; ASM International. 2000. p. 7-13.Available at: http://www.knovel.com/web/ portal/browse/display?_EXT_KNOVEL_DISPLAY_bookid $=3142 \&$ VerticalID $=0$ 
129. IARC Monographs on the Evaluation of Carcinogenic Risks to Humans. A review of human carcinogens: arsenic, metals, fibres, and dusts, nickel and nickel compounds. 2012; vol. 100C Available at: http://monographs.iarc.fr/ENG/Monographs/vol100C/mono100C-8.pdf.

130. Toxicological profile for nickel. U.S. Department of Health and Human Services, Public Health Service; Atlanta (GA): 2005. Agency for Toxic Substances and Disease Registry.

131. Grimsrud TK, Berge SR, Martinsen JI, et al. Lung cancer incidence among Norwegian nickelrefinery workers 1953-2000. J Environ Monit. 2003; 5:190-7. [PubMed: 12729252]

132. Grimsrud TK, Berge SR, Haldorsen T, et al. Can lung cancer risk among nickel refinery workers be explained by occupational exposures other than nickel? Epidemiology. 2005; 16:146-54. [PubMed: 15703528]

133. Andersen A, Berge SR, Engeland A, et al. Exposure to nickel compounds and smoking in relation to incidence of lung and nasal cancer among nickel refinery workers. Occup Environ Med. 1996; 53:708-13. [PubMed: 8943837]

134. Grimsrud TK, Berge SR, Haldorsen T, et al. Exposure to different forms of nickel and risk of lung cancer. Am J Epidemiol. 2002; 156:1123-32. [PubMed: 12480657]

135. Goodman JE, Prueitt RL, Dodge DG, et al. Carcinogenicity assessment of water-soluble nickel compounds. Crit Rev Toxicol. 2009; 39(5):365-417. [PubMed: 19514913]

136. IARC Monographs on the Evaluation of Carcinogenic Risks to Humans. A review of human carcinogens: arsenic, metals, fibres, and dusts, nickel and nickel compounds. 2012; vol. 100C Available at: http://monographs.iarc.fr/ENG/Monographs/vol100C/100C-05-Table2.3.pdf.

137. Grimsrud TK, Andersen A. Unrecognized risks of nickel-related respiratory cancer among Canadian electrolysis workers. Scand J Work Environ Health. 2012 [Epup ahead of print].

138. De Matteis S, Consonni D, Lubin JH, et al. Impact of occupational carcinogens on lung cancer risk in a general population. Int J Epidemiol. 2012; 41(3):711-21. [PubMed: 22467291]

139. National Toxicology Program. [Accessed May 27, 2012] Asbestos, Department of Health and Human Services report on carcinogens. 12th edition2011. Available at: http://ntp.niehs.nih.gov/ ntp/roc/twelfth/profiles/Asbestos.pdf

140. US EPA. [Accessed May 27, 2012] Asbestos ban and phase out. US Environmental Protection Agency. Available at: http://www.epa.gov/asbestos/pubs/ban.html

141. US Geological Survey. [Accessed May 27, 2012] Mineral commodity summaries, asbestos. 2012. Available at: http://minerals.usgs.gov/minerals/pubs/commodity/asbestos/mcs-2012-asbes.pdf

142. ATSDR. [Accessed May 15, 2012] Toxicological profile for asbestos. Agency for Toxic Substances and Disease Registry. 2001. Available at: http://www.atsdr.cdc.gov/toxprofiles/ tp61.pdf

143. Suvatne J, Browning RF. Asbestos and lung cancer. Dis Mon. 2011; 57:55-68. [PubMed: 21281831]

144. IARC Monographs on the Evaluation of Carcinogenic Risks to Humans. A review of human carcinogens: arsenic, metals, fibres, and dusts, asbestos (chrysotile, amosite, crocidolite, tremolite, actinolite, and anthophyllite). 2012; vol. 100C Available at: http://monographs.iarc.fr/ ENG/Monographs/vol100C/mono100C-11.pdf.

145. Yarborough CM. Chrysotile as a cause of mesothelioma: an assessment based on epidemiology. Crit Rev Toxicol. 2006; 36:165-87. [PubMed: 16736942]

146. Hodgson JT, Darnton A. The quantitative risks of mesothelioma and lung cancer in relation to asbestos exposure. Ann Occup Hyg. 2000; 44:565-601. [PubMed: 11108782]

147. Stayner LT, Dankovic DA, Lemen RA. Occupational exposure to chrysotile asbestos and cancer risk: a review of the amphibole hypothesis. Am J Public Health. 1996; 86(2):179-86. [PubMed: 8633733]

148. Berman DW, Crump KS. Update of potency factors for asbestos-related lung cancer and mesothelioma. Crit Rev Toxicol. 2008; 38(Suppl):11-47.

149. Stayner L, Kuempel E, Gilbert S, et al. An epidemiological study of the role of chrysotile asbestos fibre dimensions in determining respiratory disease risk in exposed workers. Occup Environ Med. 2008; 65:613-9. [PubMed: 18096653] 
150. Lenters V, Vermeulen R, Dogger S. A meta-analysis of asbestos and lung cancer: is better quality exposure assessment associated with steeper slopes of the exposure-response relationships? Environ Health Perspect. 2011; 119:1547-55. [PubMed: 21708512]

151. Loomis D, Dement JM, Richardson D, et al. Asbestos fibre dimensions and lung cancer mortality among workers exposed to chrysotile. Occup Environ Med. 2009; 67:580-4. [PubMed: 19897464]

152. Mirabelli D, Calisti R, Barone-Adesi F, et al. Excess of mesotheliomas after exposure to chrysotile in Balangero, Italy. Occup Environ Med. 2008; 65:815-9. [PubMed: 18524838]

153. Loomis D, Dement JM, Wolf SH, et al. Lung cancer mortality and fibre exposures among North Carolina asbestos textile workers. Occup Environ Med. 2009; 66(8):535-42. [PubMed: 19282317]

154. Elliott L, Loomis D, Dement J, et al. Lung cancer mortality in North Carolina and South Carolina chrysotile asbestos textile workers. Occup Environ Med. 2012; 69(6):385-90. [PubMed: 22267448]

155. Loomis D, Dement JM, Elliott L, et al. Increased lung cancer mortality among chrysotile asbestos textile workers is more strongly associated with exposure to long thin fibres. Occup Med. 2012; 69(8):564-8.

156. US Department of the Interior. US Bureau of Mines. US Geological Survey, staff. Branch of Industrial Minerals. [Accessed June 3, 2012] Crystalline silica primer. Available at: http:// minerals.er.usgs.gov/minerals/pubs/commodity/silica/780292.pdf

157. National Institute for Occupational Safety and Health. Department of Health and Human Services. Centers for Disease Control and Prevention. NIOSH Hazard review, health effects of occupational exposure to respirable crystalline silica. DHHS (NIOSH); Cincinnati (OH): 2002. Publication No. 2002-129

158. Esswein, E.; Kiefer, MS.; Snawder, J., et al. [Accessed June 4, 2012] Worker exposure to crystalline silica during hydraulic fracturing. NIOSH Science Blog, Safer Healthier Workers, Centers for Disease Control and Prevention. Available at: http://blogs.cdc.gov/niosh-scienceblog/2012/05/silica-fracking/

159. IARC Monographs on the Evaluation of Carcinogenic Risks to Humans. A review of human carcinogens: silica dust, crystalline, in the form of quartz or cristobalite. 2012; vol. 100C Available at: http://monographs.iarc.fr/ENG/Monographs/vol100C/mono100C-14.pdf.

160. Steenland K, Sanderson W. Lung cancer among industrial sand workers exposed to crystalline silica. Am J Epidemiol. 2001; 153:695-703. [PubMed: 11282798]

161. Lacasse Y, Martin S, Gagné D, et al. Dose response meta-analysis of silica and lung cancer. Cancer Causes Control. 2009; 20:925-33. [PubMed: 19184475]

162. Erren TC, Glende CB, Morfeld P, et al. Is exposure to silica associated with lung cancer in the absence of silicosis? A meta-analytical approach to an important public health question. Int Arch Occup Environ Health. 2009; 82:997-1004. [PubMed: 19066933]

163. Pelucchi C, Pira E, Piolatto G, et al. Occupational silica exposure and lung cancer risk: a review of epidemiological studies 1996-2005. Ann Oncol. 2006; 17:1039-50. [PubMed: 16403810]

164. Borm PJ, Tran L, Donaldson K. The carcinogenic action of crystalline silica: a review of the evidence supporting secondary inflammation-driven genotoxicity as a principal mechanism. Crit Rev Toxicol. 2011; 9:756-70. [PubMed: 21923565]

165. Checkoway H, Franzblau A. Is silicosis required for silica-associated lung cancer? Am J Ind Med. 2000; 37:252-9. [PubMed: 10642414]

166. Stayner L. Silica and lung cancer: when is enough evidence enough? Epidemiology. 2007; 18:234. [PubMed: 17179757]

167. Mannetje A, Brennan P, Zaridze D, et al. Welding and lung cancer in Central and Eastern Europe and the United Kingdom. Am J Epidemiol. 2012; 175(7):706-14. [PubMed: 22343633]

168. IARC Monographs on the Evaluation of Carcinogenic Risk to Humans. [Accessed June 12, 2012] Priority agents for future IARC Monographs. Available at: http://monographs.iarc.fr/ENG/ Meetings/PriorityAgents.pdf 


\section{KEY POINTS}

- If considered independently from tobacco smoking, environmentally and occupationally related causes of lung cancer are among the top 10 causes of cancer mortality in the United States.

- The goal of this review was to describe the occurrence and recent findings of the 27 agents currently listed by the International Agency for Research on Cancer (IARC) as lung carcinogens, including the categories of ionizing radiation, chemicals and mixtures, occupational exposures, metals, dust and fibers, personal habits, and other exposures.

- Supplementary new information, with a focus on analytic epidemiologic studies that have become available since IARC's most recent evaluation, is also discussed. 


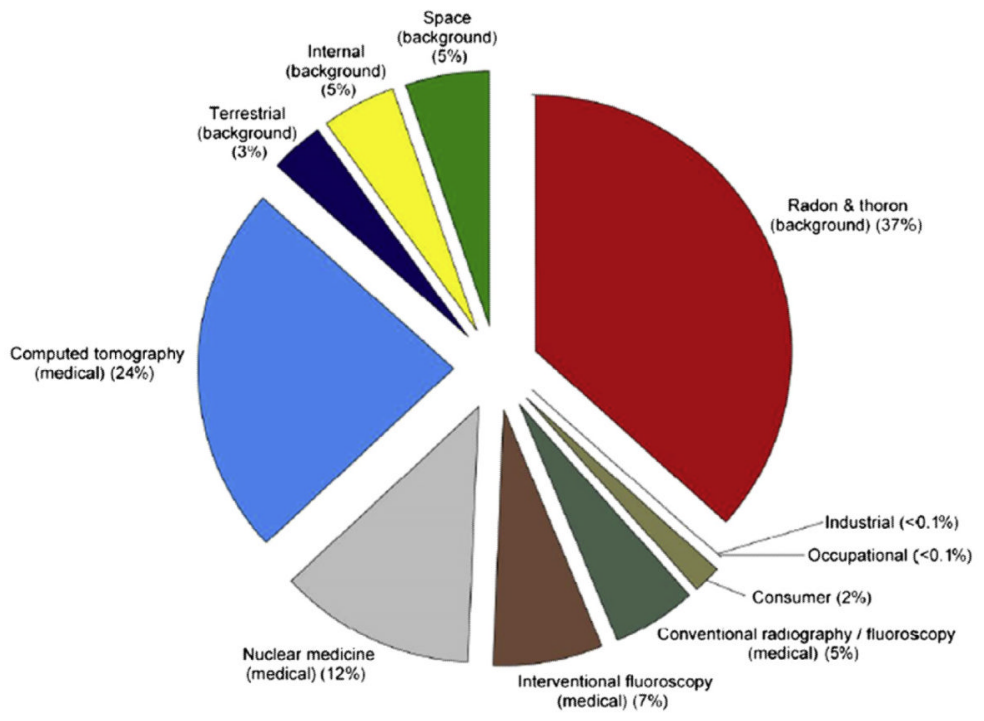

Fig. 1.

Percentage of total effective dose for the average individual in the US population from various radiation sources. Percent values rounded to the nearest $1 \%$, except for those $<1 \%$. (Reprinted with permission of the National Council on Radiation Protection and Measurements, http://NCRPpublications.org.) 


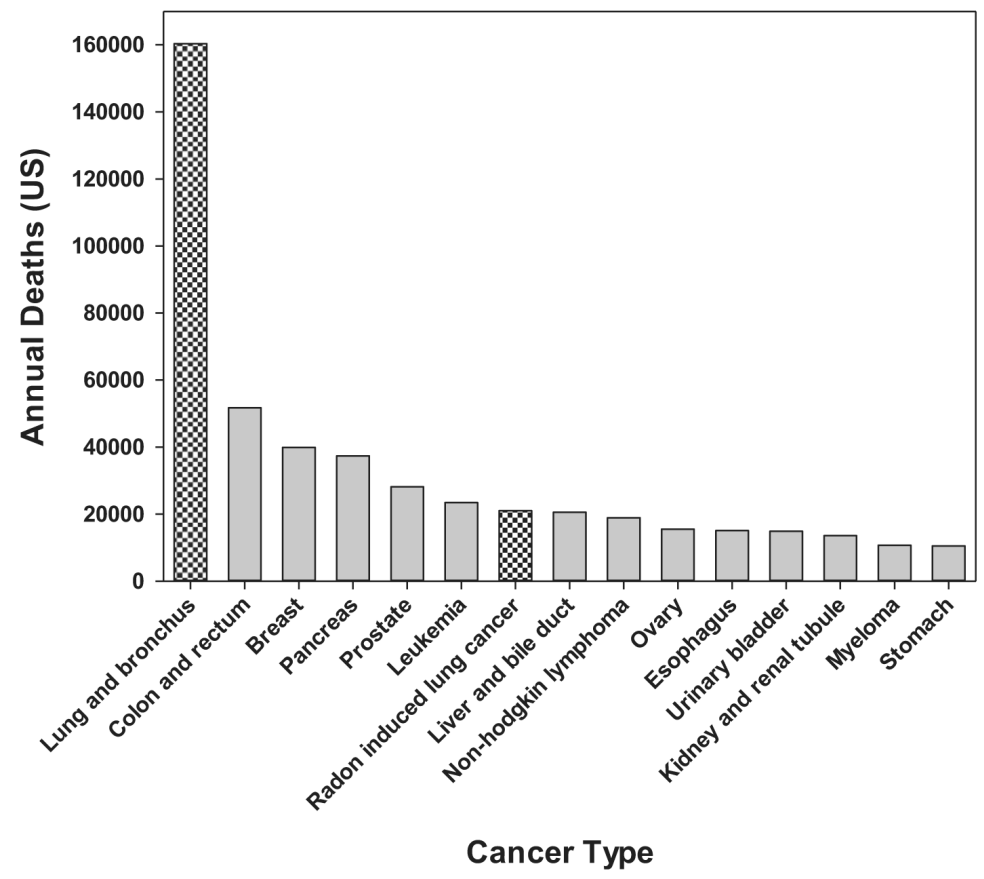

Fig. 2.

Estimated number of cancer deaths in the United States for 2012. (Source: http:// onlinelibrary.wiley.com/doi/10.3322/caac.20138/full\#fig1.) 


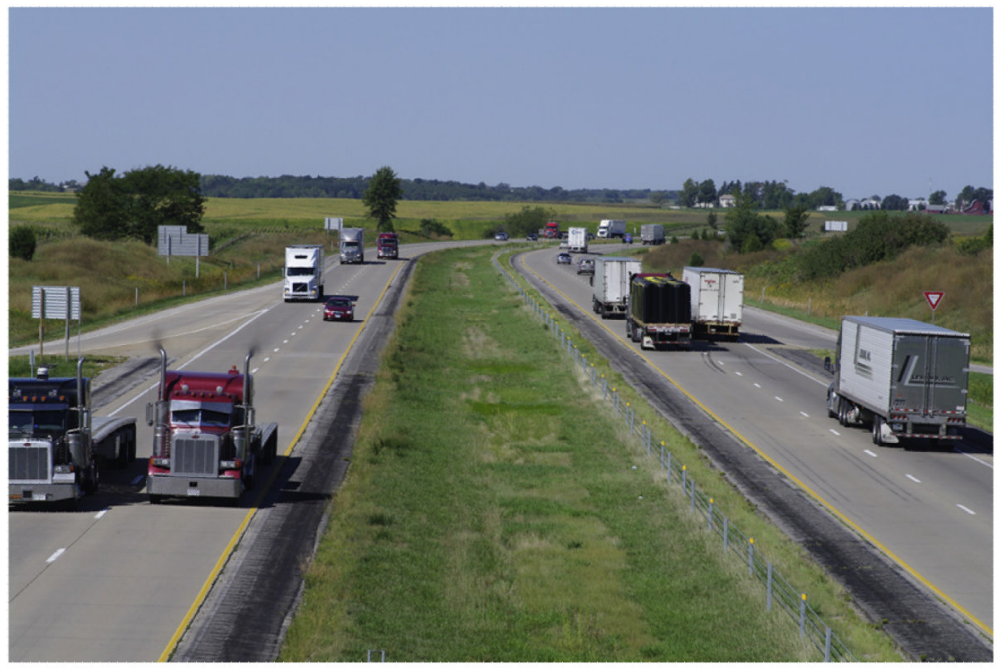

Fig. 3.

The International Agency for Research on Cancer added diesel engine exhaust to the list of Group 1 carcinogens in 2012. (Courtesy of Centers for Disease Control/The National Institute for Occupational Safety and Health (NIOSH).) 


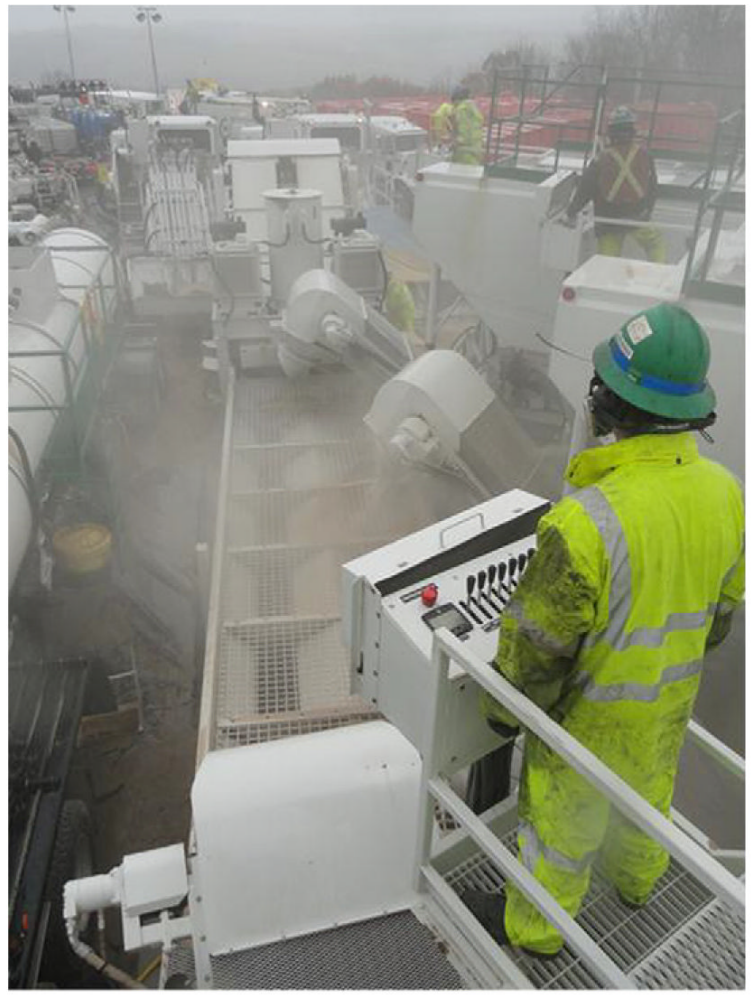

Fig. 4.

Worker exposure to silica during hydraulic fracturing. Silica dust created by worker conducting sand transfer operations. Photo shows sand mover and transfer system. (Courtesy of Centers for Disease Control/The National Institute for Occupational Safety and Health (NIOSH).) 


\section{Table 1}

Group 1 IARC carcinogens with sufficient evidence of causing lung cancer in humans and primary type of exposure

\begin{tabular}{|c|c|}
\hline Agent & Primary Exposure Type \\
\hline \multicolumn{2}{|l|}{ Ionizing radiation-all types } \\
\hline - Alpha-particle emitters & $\mathrm{E}, \mathrm{O}$ \\
\hline O Radon-222 and its decay products & $\mathrm{E}, \mathrm{O}$ \\
\hline O Plutonium-239 & $\mathrm{O}$ \\
\hline - X-radiation, gamma-radiation & $\mathrm{E}, \mathrm{O}$ \\
\hline \multicolumn{2}{|l|}{ Chemicals and mixtures } \\
\hline - Bis(chloromethyl)ether; chloromethyl methyl ether & $\mathrm{O}$ \\
\hline • Coal-tar pitch & $\mathrm{O}$ \\
\hline - Soot & $\mathrm{O}$ \\
\hline - Sulfur mustard & $\mathrm{O}$ \\
\hline - Diesel exhausts & $\mathrm{E}, \mathrm{O}$ \\
\hline \multicolumn{2}{|l|}{ Occupations } \\
\hline - Aluminum production & $\mathrm{O}$ \\
\hline - Coal gasification & $\mathrm{O}$ \\
\hline - Coke production & $\mathrm{O}$ \\
\hline • Hematite mining (underground) & $\mathrm{O}$ \\
\hline - Iron and steel founding & $\mathrm{O}$ \\
\hline - Painting & $\mathrm{O}$ \\
\hline - Rubber production industry & $\mathrm{O}$ \\
\hline \multicolumn{2}{|l|}{ Metals } \\
\hline - Arsenic and inorganic arsenic compounds & $\mathrm{E}, \mathrm{O}$ \\
\hline • Beryllium and beryllium compounds & $\mathrm{O}$ \\
\hline - Cadmium and cadmium compounds & $\mathrm{O}$ \\
\hline - Chromium (VI) compounds & $\mathrm{O}$ \\
\hline • Nickel compounds & $\mathrm{O}$ \\
\hline \multicolumn{2}{|l|}{ Dust and fibers } \\
\hline • Asbestos (all forms) & $\mathrm{E}, \mathrm{O}$ \\
\hline - Silica dust, crystalline & $\mathrm{E}, \mathrm{O}$ \\
\hline \multicolumn{2}{|l|}{ Personal habits } \\
\hline - Coal, indoor emissions from household combustion & $\mathrm{E}$ \\
\hline - Tobacco smoke, secondhand & $\mathrm{E}, \mathrm{O}$ \\
\hline
\end{tabular}


Agent

Primary Exposure Type

- Tobacco smoking

- MOPP (vincristine-prednisone-nitrogen mustard-procarbazine mixture) -

Abbreviations: E, environmental exposure; IARC, International Agency for Research in Cancer; O, occupational exposure. 